\title{
The Role of Retinal Oxidative and Nitrative Injury in Glaucomatous Neurodegeneration
}

\author{
Serdar Dogan and Mutay Aslan \\ Department of Biochemistry, Akdeniz University School of Medicine. Antalya 07070, \\ Turkey
}

\section{Introduction}

The mechanical compression theory explaining the origin of glaucoma considers elevated intraocular pressure as the most important risk factor for the disease. This theory gives support to the essential signs of glaucomatous optic neuropathy, such as increased cupping and neuroretinal rim thinning but does not explain the existence of normal tension glaucoma. Alternatively, the vascular ischemia theory supposes that vascular insufficiency in the optic nerve head results in decreased metabolic activity, which subsequently leads to increased glutamate accumulation and ganglion cell death. Indeed, a large number of studies have shown a high association between glaucomatous optic neuropathy and vascular disorders related to hypertension, diabetes and hypercholesterolemia.

Oxidative stress has been implicated to cause increased intraocular pressure by triggering trabecular meshwork degeneration and thus contributing to alterations in the aqueous outflow pathway. It has also been demonstrated that oxidative DNA damage is significantly greater in trabecular meshwork cells of glaucoma patients compared with controls. Moreover, in vivo studies in humans have shown that both intraocular pressure increase and visual field damage are significantly related to the amount of oxidative DNA damage. Similarly, severity of optic nerve damage in eyes with primary open angle glaucoma is correlated with changes in the trabecular meshwork. Retinal oxidative injury occurring in models of elevated intraocular pressure or in normal tension glaucoma also directly damage the retinal ganglion cell layer, leading to glaucomatous optic neuropathy. Free radical injury has been reported to cause caspase independent cell death in retinal ganglion cells in vitro. Furthermore, many retinal proteins exhibit oxidative modifications in experimental glaucoma, which may lead to important structural and functional alterations.

Ocular tissues and fluids contain antioxidants that play a key role in protecting against oxidative damage. However, specific activity of a major antioxidant enzyme, superoxide dismutase, demonstrates an age-dependent decline in normal human trabecular meshwork. Similarly, plasma glutathione levels assessed in patients with newly diagnosed primary open angle glaucoma and age- and gender-matched control subjects revealed that glaucoma patients exhibited significantly lower levels of reduced and total glutathione than did control subjects. 
Recent studies have also highlighted the role of nitric oxide in glaucoma by reporting the presence of inducible nitric oxide synthase in the iris-ciliary body, retina and in the glaucomatous optic nerve head of experimental rat models. This chapter will discuss the role of reactive oxygen and nitrogen species in the pathogenesis of glaucoma and examine the relevance of antioxidants in neurodegeneration associated with the disease.

Pathophysiological mechanisms leading to glaucomatous optic neuropathy remain uncertain. Mechanical compression and vascular ischemia have been suggested to play a leading role in the observed neuronal damage (Fechtner \& Weinreb, 1994). The mechanical compression theory considers elevated intraocular pressure as the most important risk factor for the disease (Yan et al., 1994). The mechanism of elevated intraocular pressure in glaucoma is impaired outflow of aqueous humour resulting from abnormalities within the drainage system of the anterior chamber angle (open-angle glaucoma) or impaired access of aqueous humour to the drainage system (angle-closure glaucoma) (Salmon et al., 2008). Aqueous humour produced by the ciliary body enters the posterior chamber, passes through the pupil into the anterior chamber and then to the trabecular meshwork in the anterior chamber angle. Trabecular meshwork drains the aqueous fluid into the canal of Schlemm (Figure 1) and is composed of beams of collagen and elastic tissue covered by trabecular cells (Salmon et al., 2008). Trabecular cells are endothelial-like cells that have capacities of phagocytosis, and the ability to produce matrix-degrading enzymes, extracellular matrix elements and transforming growth factor- $\beta$ (Tripathi et al., 1994; Yun et al., 1989).

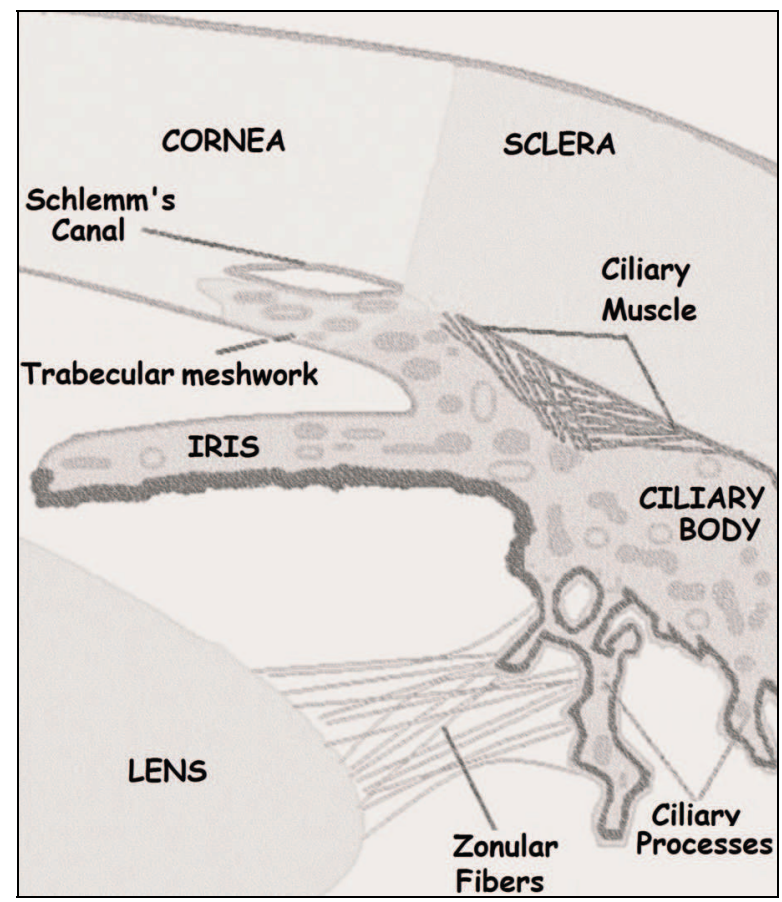

Fig. 1. Anterior segment structures and formation of aqueous humour 
Oxidative stress has been implicated to cause increased intraocular pressure by triggering trabecular meshwork degeneration and thus contributing to alterations in the aqueous outflow pathway (Sacca et al., 2007). Indeed, treatment with hydrogen peroxide $\left(\mathrm{H}_{2} \mathrm{O}_{2}\right)$ impairs trabecular meshwork cell adhesion to the extracellular matrix and causes rearrangement of cytoskeletal structures (Zhou et al., 1999). It has also been demonstrated that oxidative DNA damage is significantly greater in trabecular meshwork cells of glaucoma patients compared with controls (Izzotti et al., 2003). Moreover, in vivo studies in humans have shown that both intraocular pressure increase and visual field damage are significantly related to the amount of oxidative DNA damage (Sacca et al., 2005). Similarly, severity of optic nerve damage in eyes with primary open-angle glaucoma is correlated with changes in the trabecular meshwork (Gottanka et al., 1997).

MicroRNA (miRNA) are an abundant class of noncoding small ( 22 nucleotides) RNAs that modulate gene expression at the post-transcriptional level and participate in the regulation of many cellular functions (Wu et al, 2006; Filipowicz et al., 2008; Stefani et al., 2008) Specifically, miR-29b has been demonstrated to regulate multiple genes coding for extracellular matrix proteins, including multiple collagens, fibrillins, and elastin (Luna et al., $2009 \mathrm{~b}$ ). The role of microRNA (miRNA) in the trabecular meshwork and the potential involvement on the alterations in extracellular matrix synthesis induced by oxidative stress was studied in human trabecular meshwork cell cultures, which were generated from cadaver eyes with no history of eye disease within $48 \mathrm{~h}$ post mortem. These cells were transfected with miR-29b mimic. Chronic oxidative stress was induced by incubation at $40 \%$ oxygen for 4-5 days. Control human trabecular meshwork cell cultures were incubated at $5 \%$ oxygen. Transfection of human trabecular meshwork cells with miR-29b mimic resulted in downregulation of multiple extracellular matrix components. Chronic oxidative stress induced a significant downregulation of miR-29b in human trabecular meshwork cell lines and increased expression of several extracellular matrix genes known to be regulated by miR-29b. The increase in expression of these genes was inhibited by transfection with miR$29 \mathrm{~b}$ mimic. MiR-29b increased cell viability under both chronic oxidative stress and physiologic oxygen concentrations. These data suggest that miR-29b negatively regulates the expression of multiple genes involved in the synthesis and deposition of extracellular matrix in trabecular meshwork cells. Downregulation of miR-29b might contribute to increased expression of several extracellular matrix genes under chronic oxidative stress conditions. The balance between the activation of extracellular matrix production induced by oxidative stress and the protective effects of miR-29b could be a relevant factor in understanding how oxidative damage may lead to increased deposition of extracellular matrix in the trabecular meshwork and contribute to the elevation of intraocular pressure via obstruction of the trabeculum by deposition of an extracellular matrix (Luna et al., 2009b).

Oxidative destruction of cellular components usually accompanies ocular tissue injury in animal models of elevated intraocular pressure. Markers of oxidative stress such as protein carbonyl formation and lipid peroxidation products have been documented in experimental models of ocular hypertension. Glyceraldehyde-3-phosphate dehydrogenase, heat shock protein 72 and glutamine synthetase show a significant increase in the relative percentage of carbonyl immunoreactivity in chronic pressure induced rat models of glaucoma as compared with controls (Tezel et al., 2005) Likewise, increased retina lipid oxidation is detected in rats with elevated intraocular pressure (Ko et al., 2005). 
Circadian fluctuation of mean ocular perfusion pressure is a consistent risk factor for disease progression in normal-tension glaucoma (Choi et al., 2007). It is hypothesized that unstable ocular blood flow in patients with normal intraocular pressure can lead to reperfusion injury and result in oxidative stress (Mozaffarieh et al., 2008b). Peripheral vascular insufficiency, accompanied by restoration of blood flow, places organs at risk of additional injury by inducing a proinflammatory state reflected by enhanced superoxide $\left(\mathrm{O}_{2} \bullet-\right)$ and hydrogen peroxide $\left(\mathrm{H}_{2} \mathrm{O}_{2}\right)$ generation (Henry et al., 1990). These reactive species are usually derived from autoxidation of mitochondrial respiratory chain components (Wallace, 1999), which are also found to be present within the retinal ganglion cells, nerve fiber layer, outer plexiform layer, inner segments of photoreceptors, and the retinal pigment epithelium (Andrews et al., 1999).

A recent study has showed that mice deficient in the glutamate transporters GLAST or EAAC1 demonstrate spontaneous retinal ganglion and optic nerve degeneration without elevated intraocular pressure. In GLAST deficient mice, the glutathione level in Müller glia was found to be decreased and it was concluded that glutamate transporters are necessary both to prevent excitotoxic retinal damage and to synthesize glutathione, a major cellular antioxidant (Harada et al., 2007).

Reported findings also suggest a role for oxidative stress in the pathogenesis and progression of pseudoexfoliation glaucoma. Pseudoexfoliation syndrome is characterized by production and progressive accumulation of fibrillar extracellular material in many ocular tissues, most commonly seen on the pupillary border and anterior lens capsule (Ritch \& Schlotzer-Schrehardt, 2001). Accumulation of the exfoliation material or pigment particles in the angle can predispose to both open angle and angle-closure glaucoma (Ritch et al., 2003). The pathogenesis and etiology underlying the development of Pseudoexfoliation syndrome and the subsequent progression from Pseudoexfoliation syndrome to glaucoma remain unclear.

In summary, this review discusses the role of retinal oxidative and nitrative injury in the pathogenesis of glaucomatous neurodegeneration and examines the relevance of antioxidants in altering and/or inhibiting neuronal degeneration associated with the disease

\section{Reactive oxygen and nitrogen species}

\subsection{Sources of superoxide and reactive oxygen species}

The generation of reactive oxygen species is associated with life under aerobic conditions and reactive intermediates are produced under both physiological and pathophysiological conditions (Freeman \& Crapo, 1982). Reactive oxygen species are capable of damaging biological macromolecules such as DNA, carbohydrates or proteins. These oxygen metabolites are either radicals, e.g. hydroxyl radical $\left(\mathrm{OH}^{\bullet}\right)$, peroxyl radical $\left(\mathrm{ROO}^{*}\right)$, or reactive non-radical compounds such as singlet oxygen, peroxynitrite (ONOO-) or hydrogen peroxide $\left(\mathrm{H}_{2} \mathrm{O}_{2}\right)$ (Bergamini et al., 2004). As explained in more detail below, sources of reactive oxygen species in the eye are sunlight, mitochondria respiration, and cellular metabolic reactions.

Superoxide $\left(\mathrm{O}_{2}{ }^{-}\right)$is the primary free radical formed within the cell by the reduction of molecular oxygen (Freeman \& Crapo, 1982). The superoxide radical anion $\left(\mathrm{O}_{2}{ }^{-}-\right)$appears to play a central role as other reactive intermediates are formed from it. The respiratory chain in mitochondria is a powerful source of reactive oxygen species, primarily superoxide $\left(\mathrm{O}_{2}{ }^{-}-\right)$and consequently hydrogen peroxide $\left(\mathrm{H}_{2} \mathrm{O}_{2}\right)$, as a product of superoxide $\left(\mathrm{O}_{2}{ }^{\bullet-}\right)$ 
dismutation (Chance et al., 1979) figure 2. This is due to the probable 'leak' of single electron at the specific site of the mitochondrial electron transport chain, resulting in inappropriate single electron reduction of oxygen to superoxide $\left(\mathrm{O}_{2}{ }^{-}-\right)$(Loschen et al., 1974.) Another significant source of reactive oxygen species is inflammatory reactions, especially chronic inflammation. Inflammatory cells such as activated macrophages and neutrophils release various reactive oxygen species (hydrogen peroxide $\left[\mathrm{H}_{2} \mathrm{O}_{2}\right]$, nitric oxide [NO$\left.{ }^{\bullet}\right]$, superoxide $\left.\left[\mathrm{O}_{2}{ }^{-}-\right]\right)$and hypochlorite $(\mathrm{HOCl})$ (Fantone \& Ward, 1982). Neutrophils possess a membranebound multicomponent enzyme complex termed the NADPH oxidase that, when activated, generates large quantities of reactive oxygen species (Babior et al., 2002). This system is responsible for the neutrophil "respiratory burst" (increased respiration of phagocytosis).

The external environment can also generate reactive oxygen species from many sources including heat, UV light, therapeutic drugs, and $\chi$ - and $\gamma$ - radiation (Nikjoo et al., 1994). In an iron catalyzed Haber-weiss reaction, superoxide $\left(\mathrm{O}_{2}{ }^{-}-\right)$, ascorbate, thiols and other reductants reduce $\mathrm{Fe}^{3+}$ to $\mathrm{Fe}^{2+}$, which in turn reduces hydrogen peroxide $\left(\mathrm{H}_{2} \mathrm{O}_{2}\right)$ to form the hydroxyl radical $\left(\mathrm{OH}^{\bullet}\right)$, a potent oxidant that causes lipid oxidation (Freeman \& Crapo, 1982) figure 2. Mitochondria are also a major site for the accumulation of low molecular weight $\mathrm{Fe}^{2+}$ complexes, which promote the oxidative damage of membrane lipids, proteins, and mitochondrial DNA.

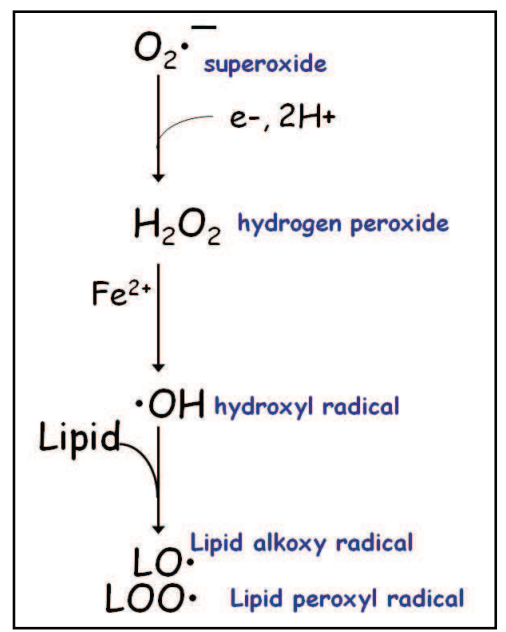

Fig. 2. Formation of reactive oxygen radicals

The hydroxyl radical $\left(\mathrm{OH}^{\bullet}\right)$ is the most reactive oxygen species. Due to its high reactivity, this radical immediately reacts with surrounding target molecules at the site where it is generated. Peroxyl radicals can be generated in the process of lipid peroxidation, which is initiated by the abstraction of a hydrogen atom from polyunsaturated fatty acids (Spiteller, 2006). Peroxyl radicals are relatively long-lived species with a considerable diffusion pathlength in biological systems. Further products generated in lipid peroxidation are aldehydes (Esterbauer et al., 1991).

While lipid peroxidation is not initiated by superoxide $\left(\mathrm{O}_{2}{ }^{-}-\right)$and hydrogen peroxide $\left(\mathrm{H}_{2} \mathrm{O}_{2}\right)$, hydroxyl radical $(\mathrm{OH} \cdot)$, alkoxy radicals $(\mathrm{RO} \cdot)$, and peroxyl radical ( $\mathrm{ROO} \bullet$ ) result in the initiation of lipid peroxidation (Kanner et al., 1987) figure 2. Lipid peroxy radicals react 
with other lipids, proteins, and nucleic acids propagating thereby the transfer of electrons and bringing about the oxidation of substrates. Cell membranes, which are structurally made up of large amounts of polyunsaturated fatty acids, are highly susceptible to oxidative attack and, consequent changes result in altered membrane fluidity, permeability, and cellular metabolic dysfunction (Spiteller, 2002).

\subsection{Sources of nitric oxide and reactive nitrogen species}

Nitric oxide $\left(\mathrm{NO}^{*}\right)$ is a free radical but is believed to be essentially a beneficial metabolite and indeed it may react with lipid peroxides and function as an antioxidant (Hogg et al., 1993). Because nitric oxide (NO•) is a free gas, it easily penetrates through biological membranes (Lancaster, 1997). Nitric oxide synthase (NOS) enzymatically generates nitric oxide (NO*) by catalyzing the oxidation of the terminal guanidino nitrogen of L-arginine, converting the precursor amino acid substrate to L-citrulline (Alderton et al., 2001). Nitric oxide synthase isoforms generally fall into two categories: (i) constitutive nitric oxide synthases (NOS-I and NOS-III) that are dependent on $\mathrm{Ca}^{2+} /$ calmodulin and (ii) inducible nitric oxide synthase (NOS-II or iNOS), the expression of which is increased by cytokines and other inflammatory stimuli. Inducible nitric oxide synthase binds $\mathrm{Ca}^{2+} /$ calmodulin at all physiologic $\mathrm{Ca}^{2+}$ concentrations and unlike the other two isoforms is not subject to $\mathrm{Ca}^{2+}$ dependent regulation (Daff, 2010). There are three nitric oxide synthase isoforms, neuronal (nNOS, NOS-I), inducible (iNOS, NOS-II), and endothelial (eNOS, NOS-III), all of which require NADPH and $\mathrm{O}_{2}$ as co-substrates. Nitric oxide synthases- I and nitric oxide synthases-III isoforms have been cloned from the human retina and retinal vascular endothelial cells, respectively (Park et al., 1994; Chakravarthy et al., 1995). Nitric oxide synthases-I has also been identified in amacrine cells, in the inner nuclear layer and in photoreceptors of the retina from different species by immunohistochemistry (Perez et al., 1995). Nitric oxide synthases-II isoform has been documented in the cornea, iris, ciliary body, neural retina, retinal glial cells, retinal pigmented epithelial cells and optic nerve head under conditions of increased intraocular pressure and uveitis (Becquet et al., 1997; Aslan et al., 2007).

\subsection{Interaction between nitric oxide and oxygen radicals}

Superoxide radical $\left(\mathrm{O}_{2} \bullet-\right)$ has a high affinity toward nitric oxide (NO•). Reaction between nitric oxide $(\mathrm{NO} \cdot)$ and superoxide $\left(\mathrm{O}_{2} \bullet-\right)$ produces a new molecule, which is called peroxynitrite (ONOO-) (Beckman et al., 1990). Peroxynitrite (ONOO-) is a highly reactive molecule and can cause extensive damage to proteins, lipids, and especially DNA molecules. The reaction of nitric oxide ( $\mathrm{NO}^{*}$ ) with metalloproteins, protein sulfhydryls and oxygen derived free radicals enables nitric oxide $\left(\mathrm{NO}^{*}\right)$ to modulate inflammation and oxidative stress (Rubbo et al., 1996).

The conjugate acid of peroxynitrite (ONOO-), peroxynitrous acid $(\mathrm{ONOOH})$, reacts by two pathways, with the first pathway yielding nitrate $\left(\mathrm{NO}_{3}{ }^{-}\right)$without forming strong oxidant intermediates. The second pathway forms hydroxyl radical $\left(\mathrm{OH}^{\bullet}\right)$ and nitrogen dioxide $\left(\mathrm{NO}_{2}\right)$, a potent oxidant that can initiate fatty acid oxidation and nitration of amino acids (Beckman et al., 1990). Peroxynitrite (ONOO-) reactivity is also influenced by $\mathrm{CO}_{2}$, with the formation of a reactive nitrosoperoxocarbonate $\left(\mathrm{ONOOCO}_{2}{ }^{-}\right)$intermediate. Consequently, $\mathrm{CO}_{2}$ stimulates both peroxynitrite (ONOO-) decay and enhances peroxynitrite (ONOO-)mediated nitration of molecules by nearly 2 -fold (Radi et al., 1999) figure 3. 
Oxidases and oxygenases, in particular, are critical sources of oxygen radical production and can lead to an overall impairment of nitric oxide ( $\mathrm{NO}^{\bullet}$ ) signaling, via the metalloprotein and free radical-mediated consumption of this vasoactive molecule. Oxidase and oxygenase activities can thus account for the functional inactivation of nitric oxide (NO•), leading to a prooxidative milieu and chronic inflammation (Aslan \& Freeman, 2007).

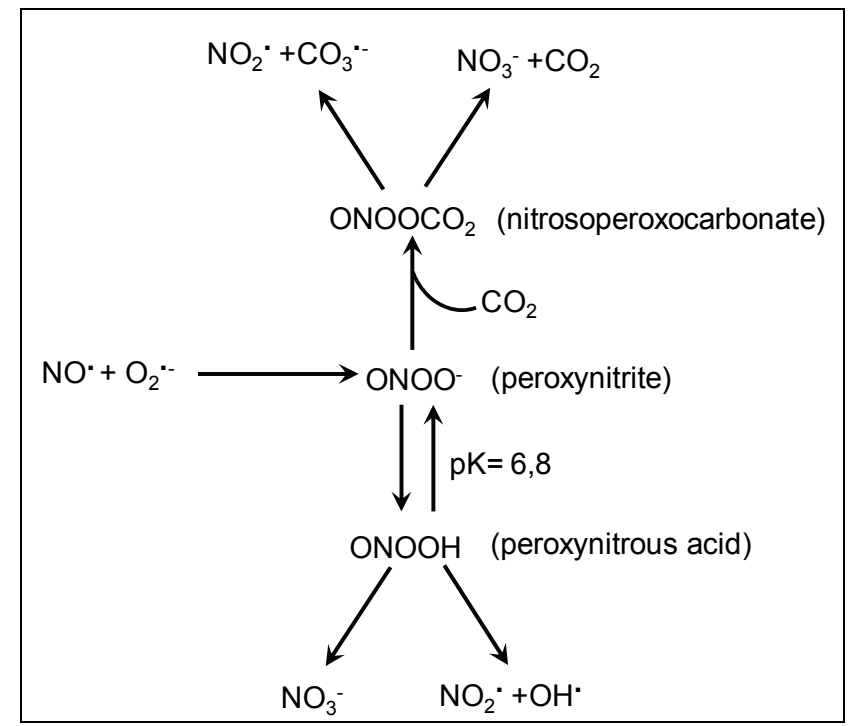

Fig. 3. Pathways of peroxynitrite formation and decay

\section{Apoptosis in glaucomatous neurodegeneration}

The major mechanism of visual loss in glaucoma is retinal ganglion cell apoptosis, leading to thinning of the inner nuclear and nerve fiber layers of the retina and axonal loss in the optic nerve (Fechtner \& Weinreb, 1994). Atrophy occuring in neurons located at magno- and parvocellular layers in the lateral geniculate nucleus of the thalamus is also reported in experimental glaucoma (Yücel et al., 2001). The lateral geniculate nucleus is the primary relay center for visual information received from the retina of the eye. (Xu et al., 2001). It is reported that neurons in parvocellular layers undergo significantly more shrinkage than neurons in magnocellular layers (Yücel et al., 2001).

In animal models of ocular hypertension, elevated intraocular pressure augments apoptosis in retinal cells, induces nitric oxide synthases-2 expression and leads to protein nitration (Aslan et al., 2006) suggesting that nitrative stress exacerbates disease progression in clinical conditions accompanied by ocular degeneration. Reported studies also demonstrate the presence of nitric oxide synthases-2 in glaucomatous optic nerve head with consistent staining of nitrotyrosine, indicating that reactive nitrogen species may contribute to retinal ganglion cell death associated with elevated intraocular pressure (Liu \& Neufeld, 2000; Shareef et al., 1999). Indeed, pharmacological studies have shown that inhibition of nitric oxide synthases- 2 by aminoguanidine provides neuroprotection to retinal ganglion cells in a rat model of chronic glaucoma (Neufeld et al., 1999). 
Nitric oxide-mediated cytotoxicity and the capacity of nitric oxide $(\mathrm{NO} \cdot)$ to induce apoptosis have been documented in macrophages (Sarih et al., 1993) astrocytes (Hu \& Van Eldik, 1996) and neuronal cells (Heneka et al., 1998). Reactive oxygen and nitrogen species are important regulators of apoptosis, which can be induced by two major pathways. The extrinsic pathway involves binding of TNF- $\alpha$ and Fas ligand to membrane receptors leading to caspase-8 activation, while the intrinsic pathway participates in stress-induced mitochondrial cytochrome c release. Released cytochrome c makes a complex with apoptotic proteaseactivating factor-1 (Apaf-1) and procaspase-9, which induces activation of caspase-9. Both pathways converge on caspase-3 activation, resulting in cellular morphological changes such as blebbing and nuclear degradation (Figure 4) (Reed, 2000).

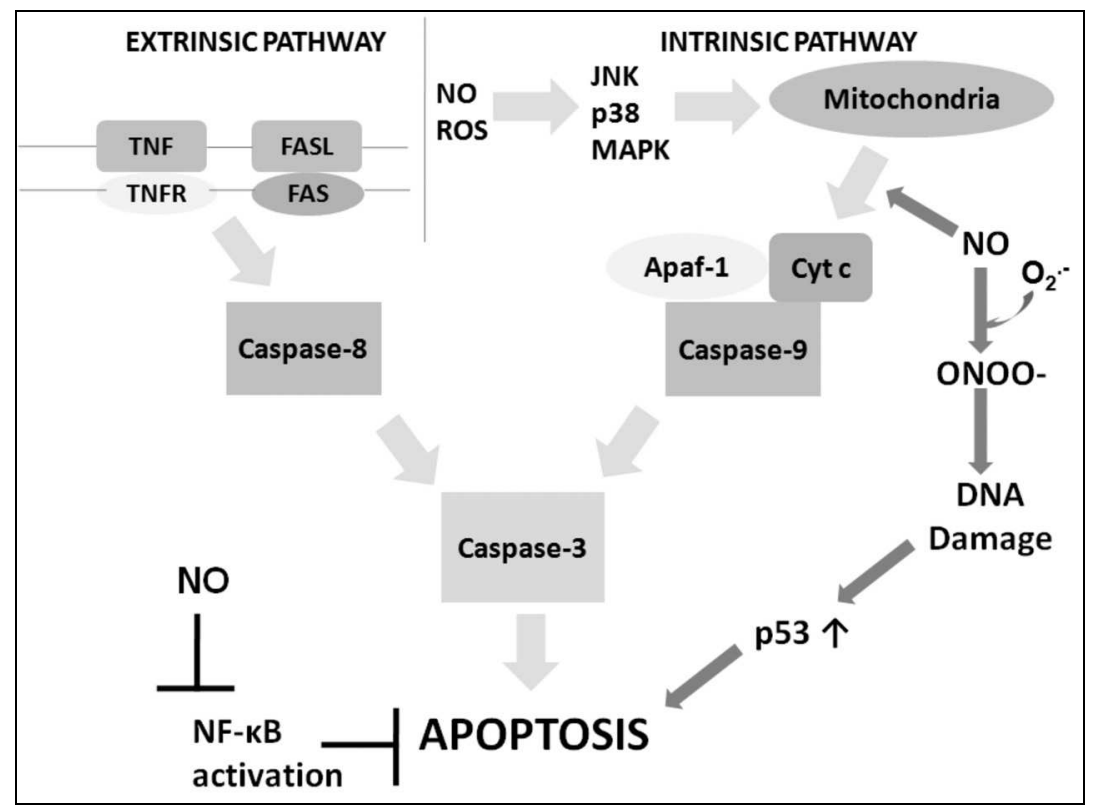

Fig. 4. Extrinsic and intrinsic pathways for apoptosis. The extrinsic pathway can be induced by members of the TNF family receptors such as TNFR and FAS. The intrinsic pathway can be activated by release of cytochrome $\mathrm{c}$ from mitochondria. In the cytosol, cytochrome $\mathrm{c}$ binds and activates Apaf-1, allowing it to bind and activate caspase-9. Caspase- 9 and -8 activate caspase-3. Main signaling components of nitric oxide (NO*)-initiated apoptotic cell death are presented in red. For details, see the text. Apaf-1, apoptotic protease-activating factor-1; Cyt c, cytochrome c; JNK, c-Jun N-terminal kinase; p38 MAPK, p38 mitogen-activated protein kinase

Nitrative and oxidative stress induce apoptotic cell death by the activation of c-Jun Nterminal kinase (JNK; also referred to as stress activated protein kinase or SAPK) and p38 mitogen-activated protein (MAP) kinase leading to caspase 3 activation (Saeki et al., 2002; Jun et al., 1999) . Nitric oxide can also directly induce cytochrome c release from the mitochondria by tyrosine nitration of cytochrome c (Hortelano et al., 1999). High concentrations of nitric oxide ( $\left.\mathrm{NO}^{*}\right)$ and peroxynitrite $\left(\mathrm{ONOO}^{-}\right)$are reported to cause DNA damage and lead to p53-mediated growth arrest and apoptosis (Kim et al., 1999). 
Nuclear factor-kB plays a protective role against apoptosis through the up-regulation of genes encoding anti-apoptotic proteins (Chen et al., 1999). Nitric oxide inhibits nuclear factor- $\mathrm{kB}$ activation, by inducing the expression of the nuclear factor- $\mathrm{kB}$ inhibitor, and stabilization of the nuclear factor- $\mathrm{kB}$ / nuclear factor- $\mathrm{kB}$ inhibitor complex (Peng et al., 1995). In contrast to nitric oxide ( $\left.\mathrm{NO}^{*}\right)$, oxidative stress activates nuclear factor-kB inhibitor kinase, which leads to the phosphorylation of nuclear factor- $\mathrm{kB}$ inhibitor and activation of nuclear factor- $\mathrm{kB}$. The activation of nuclear factor- $\mathrm{kB}$ inhibitor kinase and phosphorylation of nuclear factor- $\mathrm{kB}$ inhibitor can be blocked by antioxidants and nitric oxide (NO*) (Chen et al., 1999). With reference to reported studies one can predict that induction of apoptosis requires fine biochemical interplay between oxygen and nitrogen species. The main signaling components of nitric oxide ( $\mathrm{NO}^{*}$ )-initiated apoptotic cell death are illustrated in figure 4 .

\section{Oxidative stress and immune response regulation in glaucomatous neurodegeneration}

Oxidative stress is also linked to immunostimulatory signaling on the immunogenic aspects of glaucoma. The regulation of immune response can be in many different ways via oxidative stress in glaucoma (Tezel, 2010). One of these events is oxidative protein modifications as detected by proteomic analysis of the retina in experimental glaucoma (Tezel et al. 2005). Oxidation may change the antigenic features of these proteins, thereby serving as an immunostimulatory signal during glaucomatous neurodegeneration (Tezel, 2010). In addition to increasing antigenity, oxidative modifications may also affect the neurosupportive and immunoregulatory functions of glial cells (Tezel, 2010). Oxidized proteins, lipids, and DNA become para-inflammatory stimuli and signal to resident immune cells, mainly including microglia, to initiate an innate immune response ( $\mathrm{Xu}$ et al., 2009). With enhanced scavenger functions, microglial cells are able to remove oxidation products by phagocytosis and they may release growth factors and cytokines to promote tissue healing (Schwartz, 2003; Ransohoff \& Perry, 2009). This is in the same notion proposed for regulatory T cells (Schwartz \& Kipnis, 2002). However, if oxidative stress reaches to a certain level, the physiological homeostasis may be impaired, thereby evolving into an injury process. In this case, initial glial response expands and leads to increased production of proinflammatory cytokines (Tezel, 2010).

Complement activation constitutes another important component of the innate immune activities detected in glaucomatous neurodegeneration. The regulation of complement activation was studied in oxidative stress-mediated glaucoma. Human retinal protein samples obtained from donor eyes with or without glaucoma were analyzed by a quantitative proteomic approach using mass spectrometry. Tissue lysates were spiked with recombinant protein standards for spectral count normalization and digested with modified trypsin. Resulting peptides were loaded onto an analytical capillary chromatography column attached to an analytical reverse phase chromatography column. Ionized peptides were eluted into a linear ion trap mass spectrometer. Spectra were acquired and analyzed via tandem mass spectrometry. Cellular localization of protein expression for different complement components and regulators were also determined by immunohistochemical analysis of an additional group of human donor eyes with glaucoma compared with agematched control eyes without glaucoma. In addition, to determine the regulation of complement factor $\mathrm{H}$ by oxidative stress, in vitro experiments were performed using rat 
retinal cell cultures incubated in the presence and absence of an oxidant treatment. Proteomic and immunohistochemical analysis identified an increase in complement components $\mathrm{C} 1 \mathrm{q}$ and $\mathrm{C} 3 \mathrm{~b}$ and the membrane attack complex $\mathrm{C} 5 \mathrm{~b}-9$. In addition, several complement regulatory proteins were detected in the human retinal proteome, and glaucomatous samples exhibited a trend toward downregulation of complement factor $\mathrm{H}$ expression. In vitro experiments revealed that oxidative stress, which was also prominently detectable in the glaucomatous human retinas, downregulated complement factor $\mathrm{H}$ expression in retinal cells. These findings expand the current knowledge of complement activation by presenting new evidence in human glaucoma and support that despite important roles in tissue cleaning and healing, a potential deficiency in intrinsic regulation of complement activation, as is evident in the presence of oxidative stress, may lead to uncontrolled complement attack with neurodestructive consequences (Tezel et al., 2010).

Other consequences of oxidative stress facilitating an aberrant immune activity in glaucoma include the augmented generation of advanced glycation end products through oxidative stress-dependent processes (Tezel et al., 2007). Advanced glycation end products may act as persistent antigenic stimulus and also be immunostimulatory through a specific receptor for advanced glycation end products-mediated signaling that leads to pro-inflammatory cytokine production (Lin, 2006). Oxidative stress provides a common trigger for many downstream pathways compromising the perivascular barrier function (Pun et al., 2009) may similarly affect blood vessels in human glaucoma (Feilchenfeld et al., 2008).

The regulation of immune response through glial toll-like receptor signaling was studied in glaoucumatous oxidative stress (Luo et al., 2010). Retinal protein samples obtained from human donor eyes were analyzed by a quantitative proteomic approach involving mass spectrometry. Cellular localization of toll-like receptor-2, -3 , and -4 was also determined by immunohistochemical analysis of an additional group of human donor eyes with glaucoma and control eyes. In addition, in vitro experiments were performed in rat retinal microglia and astrocytes to determine glial toll-like receptor expression and immunoregulatory function after exposure to hydrogen peroxide $\left(\mathrm{H}_{2} \mathrm{O}_{2}\right)$-induced oxidative stress. Proteomic analyses of the human retina detected expression and differential regulation of different tolllike receptors in glaucomatous samples. Immunohistochemical analysis supported upregulated expression of toll-like receptors on both microglia and astrocytes in the glaucomatous retina. In vitro experiments provided additional evidence that oxidative stress upregulate glial toll-like receptor and MHC class II expression and cytokine production through toll-like receptor signaling and stimulate proliferation and cytokine secretion of co-cultured $\mathrm{T}$ cells during antigen presentation. This study supports the upregulation of toll-like receptor signaling in human glaucoma, which may be associated with innate and adaptive immune responses. In vitro findings showed that oxidative stressmediated glaucomatous tissue stress and may initiate the immunostimulatory signaling through glial toll-like receptors (Luo et al., 2010).

\section{The role of retinal oxidative and nitrative injury in glaucomatous neurodegeneration}

\subsection{Protein oxidation in glaucomatous neurodegeneration}

Protein carbonyl formation is a widely utilized marker for protein oxidation (Stadtman et al., 1991). The measurement of carbonyl groups is considered to be a good estimation for the extent of oxidative damage to proteins. Carbonyls, formed following reactive oxygen 
species-mediated oxidation of sugar and membrane lipids, are able to form adducts commonly known as CO-proteins (proteins bearing carbonyl groups) with structural proteins, causing alterations in their biological activity (Shacter, 2000). Reactive carbonyl groups on proteins can also be formed by direct oxidation of protein side-chains (Reznick \& Packer, 1994). Reactive oxygen species may oxidize amino acid residue side-chains into ketone or aldehyde derivatives. Histidine, arginine, and lysine are the most susceptible amino acids for reactive oxygen species-mediated protein carbonyl formation (Stadtman \& Berlett, 1997).

Most methods detecting protein-bound carbonyls are based on the covalent reaction of the carbonylated protein side chain with 2,4 dinitrophenyl-hydrazine and detection of 2,4dinitrophenylhydrazone groups with a specific anti-dinitrophenyl antibody. Proteinhydrazone produced via the 2,4 dinitrophenyl-hydrazine reaction can also be quantified spectrophotometrically at an absorbance between 360-385 nm (Reznick \& Packer, 1994).

Serum protein carbonyl levels measured in 50 patients with pseudoexfoliation glaucoma and in 55 healthy controls revealed a significant increase in the diseased group (Yagci et al., 2006). Protein carbonyl formation was also identified via proteomic analysis in a chronic pressure induced rat model of glaucoma (Tezel et al., 2005). In the reported study, carbonylated protein side chains present in control and ocular hypertensive retinal protein lysates were reacted with 2,4 dinitrophenyl-hydrazine and the formation of 2,4dinitrophenyl-hydrazone groups were identified with anti-dinitrophenyl antibody via twodimensional polyacrylamide gel electrophoresis. Approximately 60 protein spots, detected on 2D-oxyblots exhibited protein carbonyl immunoreactivity in ocular hypertension. Three of these proteins showed a significant increase in the relative percentage of carbonyl immunoreactivity as compared with controls. These spots were excised and in-gel digested prior to identification by matrix-assisted laser desorption ionization time-of flight mass spectrometry. Spectral masses obtained by matrix-assisted laser desorption ionization timeof flight mass spectrometry were analyzed via bioinformatics through the Mascot and Profound search engines. Identified proteins through mass fingerprinting were glyceraldehyde-3-phosphate dehydrogenase, heat shock protein 72 and glutamine synthetase.

Glyceraldehyde-3-phosphate dehydrogenase is a glycolytic enzyme, which catalysis the phosphorylation of glyceraldehyde-3-phosphate. The active site of this enzyme contains reactive $\mathrm{SH}$-groups (Olsen et al., 1975), which can easily be oxidized in the presence of hydrogen peroxide $\left(\mathrm{H}_{2} \mathrm{O}_{2}\right)$ or in the presence of systems producing superoxide $\left(\mathrm{O}_{2}{ }^{-}-\right)$ (Schmalhausen et al., 1999). Mild oxidation of glyceraldehyde-3-phosphate dehydrogenase results in the uncoupling of the oxidation and phosphorylation in glycolysis and decreases the content of ATP in the cell (Danshina et al., 2001). Thus, the oxidation of glyceraldehyde3-phosphate dehydrogenase leading to altered enzyme activity can play a key role in the development of different pathological processes including neuronal cell death associated with glaucoma.

Posttranslational oxidative modification of heat shock protein 72 may have deleterious concequences on protein function. The primary function of heat shock protein 72 is to serve as an intracellular molecular chaperone of naive, aberrantly folded, or mutated proteins (Lindquist \& Craig, 1988). Indeed, the expression of heat shock protein 72 in cultured rat retinal ganglion cells has been shown to increase tolerance to hypoxic and excitotoxic injury (Caprioli et al., 1996). Similarly, retinal ganglion cell protection was observed in a rat model of glaucoma treated with a heat shock protein inducer, geranylgeranylacetone (Caprioli et 
al., 2003). Transient increase of Hsp expression in some regions of the brain has been reported following oxidative injury. Hsp70 is induced in injured neurons, while upregulation of Hsp27 occurs predominantly in glial cells following ischemic stress (Kalmar \& Greensmith, 2009).

Glutamine synthetase catalyzes the conversion of glutamate to glutamine and is a key enzyme participating in the metabolism of the major excitatory neurotransmitter, glutamate (Albrecht et al., 2007). Glutamine synthetase expression, also shown in retinal ganglion Müller cells (Linser et al., 1984), thus plays an important protective role against neuronal excitotoxicity. The effect of carbonyl formation on the function of glutamine synthetase remains to be elucidated but may have potential consequences on retinal ganglion cell death associated with glaucoma.

\subsection{Glyco-oxidation in glaucomatous neurodegeneration}

Advanced glycation end products form via non-enzymatic condensation reactions between reducing sugars and $\varepsilon$-amino groups or $\mathrm{N}$-terminal groups. These glycation modifications occur preferentially on lysine and arginine amino acids, although they can occur on free amine containing lipids and DNA and proceed spontaneously via a complex series of chemical rearrangements to yield reactive products with varying crosslinking, pigmentation, and fluorescence properties (Brownlee et al., 1988). If oxidation accompanies glycation then the products formed are known as glyco-oxidation products (Fu et al., 1994). Advanced glycation end products are measured by spectroscopic and fluorimetric methods, exploiting their particular values of absorption $(280 \mathrm{mn}$ ) and fluorescence (emission at $440 \mathrm{mn}$, excitation at $370 \mathrm{mn}$ ). However, these methods are not very specific and can only give indications on the general trend of the glycation process (Brownlee et al., 1988). More recently, radioimmunoassay and enzyme-linked immunosorbent assay methods have been developed, using polyclonal antibodies raised against advanced glycation end products and obtained in vitro from the glycation reaction of glucose with ribonuclease (Lapolla et al., 2005).

Although, nonenzymatic glycation of proteins is an important phenomenon in the development of vascular disease complications like macro- and microangiopathy (Bierhaus et al., 1998) it has also been recently observed in glaucoma (Tezel et al., 2007). Lens capsules of patients with Pseudoexfoliation syndrome and pseudoexfoliation glaucoma were immunostained to investigate the presence carboxymethylysine, a common glyco-oxidation product. In most of the obtained samples carboxymethylysine staining could be detected in epithelial cells of the lens capsules. However, direct correlation between clinical course and immunohistochemical reactivity could not be found (Zoric et al., 2006).

The formation of advanced glycation end products leads to protein cross-linking and causes the destruction of cellular structures (Brownlee et al., 1988). Indeed, advanced glycation end products inhibitors such as aminoguanidine, has been reported to retard the development of vascular disease complications in animal models by preventing the formation of advanced glycation end products in various proteins including collagen (Yucel et al., 2006; Vasan et al., 2003).

In a recent study, immunoperoxidase and double-immunofluoorescence labeling were performed to determine advanced glycation end products and their receptor in the retina and optic nerve head obtained from donor eyes with glaucoma and age matched controls. Enhanced accumulation of advanced glycation end products and an up-regulation of receptor for advanced glycation end products were detectable in the glaucomatous retina 
and optic nerve head compared with controls (Tezel et al., 2007). In the reported study, cellular localization of advanced glycation end products and receptor for advanced glycation end products were determined via double immunolabeling with antibodies against glial fibrillary acidic protein, antivimentin and brn-3, markers of astrocytes, Müller cells, and retinal ganglion cells, respectively. Increased advanced glycation end products immunolabeling in glaucoma was mainly observed in the extracellular compartment and included laminar cribriform plates in the optic nerve head, while immunolocalization of receptors for advanced glycation end products was predominantly associated with astrocytes (Tezel et al., 2007).

\subsection{Lipid peroxidation in glaucomatous neurodegeneration}

Reactive oxygen species, generated during oxidative stress can induce peroxidation of lipids (either cellular membrane lipids or circulating lipoprotein molecules) and generate highly reactive aldehydes (Spiteller, 2006). The resultant end products, malondialdehyde or 4hydroxynonenal are well-known markers in the pathologic molecular process in oxidative stress (Poli \& Schaur, 2000). 4-hydroxynonenal derives from $\omega-6$ polyunsaturated fatty acids like linoleic and arachidonic acid, whose conjugated double bonds are an easy target for species that can extract a hydrogen atom or add to a double bond (Poli et al., 2004).

Although lipid peroxidation has been quantitatively assessed by measuring malondialdehyde levels by the thiobarbituric acid-reacting substances assay, Thiobarbituric acid-reacting substances is considered to be a nonspecific marker of membrane lipid peroxidation, likely due to reaction of thiobarbituric acid with non-lipid moities (Yeo et al.,

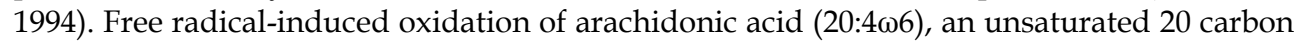
fatty acid released from membrane phospholipids, results in formation of F2- and D2/E2isoprostanes (IP) (Pratico, 1999). Recent studies indicate that measurement of IP provides a reliable noninvasive approach to assess lipid peroxidation in vivo (Morrow, 2000).

A number of DNA adducts arising from lipid hydroperoxide-derived products have been identified by liquid chromatography-mass spectrometry (Blair, 2008). Malondialdehyde is one of the most studied lipid hydroperoxide-derived product that causes DNA damage (Marnett et al., 2003). However, the cyclic DNA-adduct it forms with dGuo (M1dG) is not a specific marker of lipid hydroperoxide-mediated DNA-adduct formation. M1dG may be a useful biomarker of endogenous DNA damage resulting from oxidative stress (Blair, 2008). Lipid hydroperoxide-DNA adducts, which are repaired and appear in the urine, can be used as surrogate biomarkers of DNA damage. Urinary heptanone-etheno (Hع) dAdo (HedAdo), HedGuo, and HedCyd, which are formed exclusively by lipid hydroperoxide-mediated DNA damage, can be useful urinary biomarkers (Blair, 2008). Heptanone-etheno dCyd is highly mutagenic in cells (Pollack et al., 2006) and thus its quantification in the urine may have a clinical relevance.

UV spectrophotometry and fluorescent analysis were used to study the accumulation of conjugated dienes, end products of lipid peroxidation, in lipid extracts from lenses, aqueous humour and trabecular tissues, obtained from 49 eyes of patients with primary open angle glaucoma. Lipid peroxidation products have been found in significantly higher concentrations in the aqueous humour and trabecular tissue of glaucoma patients compared with control subjects (Babizhayev \& Bunin, 1989). Similarly, a 2.5-fold increase in malondialdehyde levels were observed in lens capsule samples of patients with pseudoexfoliation syndrome when compared with normal age-matched control subjects (Gartaganis et al., 2007). Likewise, the 
mean concentration of 8-isoprostaglandin F2 measured in the aqueous fluid from patients with Pseudoexfoliation syndrome was significantly higher than those of age-matched control patients (Koliakos et al., 2003).

Increased vitreous and retina malondialdehyde levels were also detected in rats with elevated intraocular pressure (Yucel et al., 2005). As mentioned previously, peroxidation of polyunsaturated fatty acids results in the formation of multiple aldehydes including 4hydroxynonenal, which is capable of inducing apoptosis in neuronal cells (Kruman et al., 1997). The dose and time dependent effects of 4-hydroxynonenal were studied on primary cultures of human optic nerve head astrocytes, generated from normal and glaucomatous human eyes (Malone \& Hernandez, 2007). Treatment with 4-hydroxynonenal at concentrations of $50 \mathrm{mM}$ and higher led to a greater than $50 \%$ reduction in cell viability of normal optic nerve head astrocytes over $6 \mathrm{~h}$ (Malone \& Hernandez, 2007).

Glutathione is the most abundant non protein thiol in the cell and a key cellular antioxidant important in the inactivation of 4-hydroxynonenal (Dickinso et al., 2004). A significant depletion of glutathione levels was observed in normal astrocytes after exposure to 4hydroxynonenal for over an hour (Kruman et al., 1997). Basal levels of glutathione in primary cultures of human optic nerve head astrocytes from glaucomatous eyes were reported to be below the level of detection compared with primary cultures from normal astrocytes (Malone \& Hernandez, 2007). This finding suggests the presence of an altered antioxidant defence mechanism in glaucoma. A significant increase in glutathione levels were measured in both normal and glaucomatous astrocytes $24 \mathrm{~h}$ after 4-hydroxynonenal removal (Malone \& Hernandez, 2007).

Human optic nerve head astrocytes treated with $25 \mu \mathrm{M}$ 4-hydroxynonenal for over an hour induced expression of glutamate cysteine ligase catalytic subunit (Malone \& Hernandez, 2007), leading to an increase in glutathione synthesis thereby enhancing cellular oxidant defense mechanisms (Dickinson et al., 2002). Expression of aldoketo reductase 1C, which metabolizes 4-hydroxynonenal to an inactive metabolite, was also elevated in optic nerve head astrocytes treated with $25 \mu \mathrm{M}$ 4-hydroxynonenal for over an hour (Malone \& Hernandez, 2007). The expression of glutathione S-transferase, which catalyzes the conjugation of 4-hydroxynonenal to glutathione, was similarly induced in optic nerve head astrocytes via 4-hydroxynonenal incubation (Malone \& Hernandez, 2007). Induction of the aforementioned enzymes confers a protection mechanism against oxidative damage in optic nerve head neuronal cells in humans.

Increased lipid peroxidation accompanied by altered antioxidant enzyme activities was also observed in rats with glaucoma induced by 6 week injection of hyaluronic acid into the anterior chamber (Moreno et al., 2004). Retina lipid peroxidation, measured as thiobarbituric acid-reacting substances significantly increased in a time and hypertension dependent manner. The observed increase in thiobarbituric acid-reacting substances was accompanied by a decrease in glutathione, catalase and superoxide dismutase enzyme activities suggestive of an altered antioxidant defense mechanism (Moreno et al., 2004).

\subsection{Protein nitration in glaucomatous neurodegeneration}

Aromatic nitration is recognized to be a mediator of pathological conditions and signaling events encompassing nitric oxide ( $\mathrm{NO}^{*}$ ) and oxidative stress. Numerous in vitro biochemical studies have demonstrated that nitration of protein tyrosine residues can alter protein function (Cassina et al., 2000). It has been shown that 3-nitrotyrosine ( $\mathrm{NO}_{2} \mathrm{Tyr}$ ), 3-bromotyrosine and 3-chlorotyrosine, selective markers of protein nitration (MacPherson et 
al., 2001). Indeed, the detection of protein $\mathrm{NO}_{2} \mathrm{Tyr}$ is commonly used as a diagnostic marker of nitric oxide (NO•).-derived oxidants in both human disease states and animal models (Aslan et al., 2003). Various techniques including western blotting, enzyme-linked immunosorbent assay, immunochemistry, HPLC and mass spectrometry are employed to determine the formation of $\mathrm{NO}_{2} \mathrm{Tyr}$ in a variety of disease states (Aslan et al., 2003).

Elevated intraocular pressure augments nitric oxide synthase-2 expression, retinal protein nitration and apoptosis (Aslan et al., 2006) and suggests that protein nitration and apoptosis exacerbate disease progression in clinical conditions accompanied by ocular degeneration. Thus, selective inhibiton of nitric oxide synthase- 2 and appropriate intraocular pressurelowering may prevent long-term visual loss and lead to improvement in the management of glaucoma. Indeed, pharmacological studies have shown that inhibition of nitric oxide synthases-2 by aminoguanidine provides neuroprotection of retinal ganglion cells in a rat model of chronic glaucoma (Neufeld et al., 1999). Nitric oxide synthase- 2 immunostaining observed in glaucomatous optic nerve head suggests that it may contribute to retinal ganglion cell death associated with elevated intraocular pressure (Liu \& Neufeld, 2000; Shareef et al., 1999).

\subsection{DNA oxidation in glaucomatous neurodegeneration}

Oxidative DNA damage can lead to DNA-protein cross linking, strand breaks and base modifications. Oxidative DNA damage is assessed by measuring levels of 8-hydroxy-2'deoxyguanosine (8-OH-dG), an indicator of oxidative DNA damage (Dizdaroglu, 1992). 8-hydroxy-2'-deoxyguanosine (8-OH-dG) can be measured by high pressure liquid chromatography with electrochemical detection or by gas chromatography/mass spectrometry, a technique that combines gas-liquid chromatography and mass spectrometry to identify different substances within a test sample (Shigenaga et al., 1994). DNA strand breaks can be detected in tissues and cells via alkaline elution assay or terminal deoxynucleotide transferase-mediated in situ end-labeling, respectively (Collins \& Horvathova, 2001).

Elevated intraocular pressure due to reduction in aqueous outflow facility is a major causal effect in glaucoma (Yan et al., 1994). The eye's outflow system consists of a series of endothelial cell-lined structures in the angle of the anterior chamber, which also include the trabecular meshwork. Levels of 8-hydroxy-2'-deoxyguanosine (8-OH-dG), a marker of oxidative DNA damage, was determined in human trabecular meshwork specimens collected from patients with primary open angle glaucoma (Sacca et al., 2005). The relationship between DNA oxidation, intraocular pressure and visual field damage and disease duration were also evaluated. Eight-hydroxy-2'-deoxyguanosine (8-OH-dG) was measured in extracted DNA samples by using a ${ }^{32} \mathrm{P}$-postlabeling procedure (Sacca et al., 2005). A statistically significant correlation was also found among oxidative DNA levels, visual field damage and intraocular pressure. It was concluded that oxidative DNA damage may induce human trabecular meshwork degeneration, leading to increased intraocular pressure.

Glutathione S-transferases are ubiquitous multifunctional enzymes, which play a key role in cellular detoxification. These enzymes protect cells against toxicants by conjugating them to glutathione, thereby neutralizing their electrophilic sites and increasing the products watersolubility (Mannervik et al., 1985). Glutathione S-transferase M1 gene polymorphism was examined in human trabecular meshwork specimens collected from 45 primary open angle 
glaucoma patients undergoing therapeutical eye surgery (trabeculectomy) and unaffected controls (Izzotti, 2003). An association was found between Mu-class glutathione S-transferase null allele and primary open angle glaucoma, suggesting a possible genetic predisposition of defective Mu-class glutathione S-transferase null allele in the disease. Primary open angle glaucoma patients having $\mathrm{Mu}$-class glutathione S-transferase null allele deletion had 2.2-fold higher 8-hydroxy-2'-deoxyguanosine (8-OH-dG) amounts than Muclass glutathione S-transferase null allele positive subjects. In addition, Mu-class glutathione S-transferase null allele deletion was significantly more frequent in primary open angle glaucoma patients than in unaffected controls. 8-hydroxy-2'-deoxyguanosine (8-OH-dG) was increased (3.6-fold) in primary open angle glaucoma patients as compared with controls. Preliminary results from this study indicate that glutathione S-transferase genes are expressed in human trabecular meshwork under physiological conditions and that oxidative DNA damage is associated with primary open angle glaucoma.

\section{Potential applications of antioxidants in glaucomatous neurodegeneration}

As presented herein, chronic oxidative stress is involved in glaucoma pathogenesis, most notably, its age-dependent clinical onset. Ocular tissues and fluids contain antioxidants that play a key role in protecting against oxidative damage. Superoxide $\left(\mathrm{O}_{2}{ }^{-}-\right)$is removed either by cytoplasmic, mitochondrial or extracellular superoxide dismutases, which dismutate superoxide $\left(\mathrm{O}_{2} \cdot-\right)$ to yield hydrogen peroxide $\left(\mathrm{H}_{2} \mathrm{O}_{2}\right)$ and oxygen $\left(\mathrm{O}_{2}\right)$ (Fridovich, 1986). Hydrogen peroxide formed in the anterior segment tissues of the eye is removed by the heme-containing enzyme catalase or by glutathione peroxidase (Costarides et al., 1991). The specific activity of superoxide dismutase and catalase can be measured in both normal fresh human cadaver trabecular meshwork (De La Paz \& Epstein, 1996) and in the iris and corneal endothelium of rabbits (Riley, 1990). Specific activity of superoxide dismutase, but not catalase, demonstrates an age-dependent decline in normal cadaver human trabecular meshwork. However, age-dependent decline of catalase activity is only observed in the iris and corneal endothelium of rabbits.

A decrease in serum superoxide dismutase and catalase activity was also observed in patients with Pseudoexfoliation syndrome compared with age-matched controls (Zoric et al., 2006). Glutathione and oxidized glutathione levels were also decreased in pseudoexfoliation lens epithelial cells compared with non- pseudoexfoliation controls (Gartaganis et al., 2007). Furthermore, mean ascorbic acid concentration in the aqueous humour of patients pseudoexfoliation syndrome was significantly lower than that found in control patients (Koliakos et al., 2003).

Glutathione and ascorbic acid (Vitamin C) are low molecular weight antioxidants that can be detected in the aqueous humor of humans (Richer \& Rose, 1998). Rapid loss of Vitamin E during lipid peroxidation can be diminished by ascorbic acid, which is known to recycle the Vitamin E radical (May, 1999). No significant difference was found in blood levels of ascorbic acid measured in 38 patients with chronic open-angle glaucoma and 12 controls (Asregadoo, 1979). On the contrary, plasma glutathione levels assessed in 21 patients with newly diagnosed primary open angle glaucoma and 34 age- and gender-matched control subjects revealed that glaucoma patients exhibited significantly lower levels of reduced and total glutathione than did control subjects (Gherghel et al., 2005).

Lutein and zeaxanthin are oxygenated carotenoids that form the macular pigment. Of the 10 carotenoids that have been reported in the human serum, only two, zeaxanthin and lutein 
are found in the human retina (Roberts et al., 2009). Although it is suggested that zeaxanthin and lutein are concentrated in the retina because of their ability to cross the blood brain barrier of the retinal pigment epithelium and scavenge free radicals (Roberts et al., 2009), no strong association was found between dietary intake of lutein and zeaxanthin and the risk for glaucoma (Rhone \& Basu, 2008). Conversely, a recent study showed that treatment with astaxanthin, a naturally occurring carotenoid pigment and a powerful biological antioxidant, reduced oxidant-induced protein oxidation, lipid peroxidation and apoptotic cell death in experimental rat models of elevated intraocular pressure (Cort et al., 2010).

Polyphenolic flavonoids (tea, coffee, wine, dark chocolate and ginkgo bilboa), alpha lipoic acid, coenzyme Q10 and melatonin are natural substances with antioxidant activity in glaucomatous neurodegeneration (Mozaffarieh et al., 2008a).

The effects of resveratrol, which is a naturally occurring polyphenol found in berries, nuts, and red wine was studied in primary porcine trabecular meshwork cells subjected to chronic oxidative stress (Luna et al., 2009a). Primary porcine trabecular meshwork cells were submitted to chronic treatment with resveratrol or vehicle every three days for 15 days. Cells under resveratrol or vehicle treatment were incubated under oxidative stress conditions (40\% oxygen) and control cultures were treated with vehicle and incubated at physiological oxygen concentration (5\%). The level of endogenous reactive oxygen species was significantly decreased by resveratrol treatment $(4$ fold) compared with cells treated with vehicle. The amount of intracellular reactive oxygen species in resveratrol-treated cells under oxidative stress was similar to that of non-stressed control cells. The induction of mRNA expression of the inflammatory markers interleukin-1a, $-6,-8$ and endothelialleukocyte adhesion molecule after chronic oxidative stress was significantly inhibited by chronic treatment with resveratrol. The accumulation of carbonylated proteins induced by oxidative stress was significantly lower in resveratrol-treated samples compared with samples treated with vehicle under oxidative stress. Resveratrol-treated cells showed protection against apoptosis after acute oxidative stress $(200,400$, and $800 \mu \mathrm{M}$ of hydrogen peroxide $\left.\left[\mathrm{H}_{2} \mathrm{O}_{2}\right]\right)$, when compared with cells treated with vehicle. Vehicle-treated cells showed a linear correlation between hydrogen peroxide $(\mathrm{H} 2 \mathrm{O} 2)$ concentration and apoptosis; cells treated with resveratrol exhibited protection against apoptosis in all hydrogen peroxide $\left(\mathrm{H}_{2} \mathrm{O}_{2}\right)$ concentrations. Resveratrol treatment did not result in significant changes in proliferation and in the amount of DNA damage when compared with cells treated with vehicle. The data suggests that resveratrol could potentially have a role in preventing the trabecular meshwork tissue abnormalities observed in primary open angle glaucoma (Luna et al., 2009).

The antioxidative properties of ginkgo are due to its direct radical scavenging activity. Ginkgo biloba prevents oxidative damage to mitochondria, exhibits neuroprotective properties, inhibits LDL oxidation, has a relaxing effect on vascular walls, and an antagonistic action on platelet activating factor (Mozaffarieh et al., 2008a). Administration of ginkgo increases ocular blood flow velocity in patients (Chung et al., 1999), and improves visual field in normal tension glaucoma patients (Quaranta at al., 2003). The beneficial properties of ginko biloba suggest it to be of major therapeutic value in the treatment of glaucoma (Ritch, 2000).

The water and fat soluble vitamin alpha lipoic acid is found in foods such as red meat, liver, and yeast. Alpha lipoic acid is capable of regenerating several other antioxidants back to their active states, including vitamin C, vitamin E, glutathione and coenzyme Q10 (Mozaffarieh et al., 2008a). 
Coenzyme Q10 is a coenzyme for the inner mitochondrial enzyme complexes involved in energy production within the cell (Choi et al., 2005). Coenzyme Q10 has been demonstrated to prevent lipid peroxidation and DNA damage induced by oxidative stress (Tomasetti et al., 2001). Oral administration of ubiquinone was shown to be useful in mitigating cardiovascular side-effects without affecting intraocular pressure in glaucoma patients (Takahashi et al., 1989).

Melatonin reduces the elevation of cGMP by suppressing nitric oxide synthase activity, indicating a neuroprotective role in the retina (Mozaffarieh et al., 2008a; Sa'enz et al., 2002). Findings indicate that melatonin reduces nitric oxide (NO*)-induced retinal oxidative damage both in vitro and in vivo. Furthermore, several of the metabolites that are generated when melatonin inactivates toxic reactants are themselves free radical scavengers (Mozaffarieh et al., 2008a). In addition, melatonin stimulates a number of antioxidative enzymes, which further promote antioxidative protection (Rodriguez et al., 2004).

The role of dorzolamide, which is a topical carbonic anhydrase inhibitor that plays significant intraocular pressure-lowering activity and vasoactive effect, was studied on the oxidative/antioxidant status of aqueous humor in patients with primary open angle glaucoma (Zanon-Moreno et al., 2009). One hundred thirty patients were divided into three groups; patients with primary open angle glaucoma without dorzolamide administration $(n=34)$; patients with primary open angle glaucoma with dorzolamide administration $(n=36)$; and subjects with cataract (comparative group, $n=60)$. Oxidative activity was measured in the aqueous humor by malondialdehyde determination by thiobarbituric acidreacting substances assay. Antioxidant status was assessed in the aqueous humor samples by measuring the superoxide dismutase activity and the total antioxidant status. Oxidative activity was significantly higher in both glaucoma groups than in the cataract group and was significantly higher in subjects without dorzolamide administration. Superoxide dismutase activity was significantly higher in both glaucoma groups than in the cataract group, and was significantly higher in glaucoma without dorzolamide administration than in glaucoma with dorzolamide treatment. Total antioxidant status was significantly decreased in both glaucoma groups compared with the cataract group, and was more significantly decreased in glaucoma without dorzolamide administration than in glaucoma with dorzolamide administration (Zanon-moreno et al., 2009). The data suggest that topical administration of dorzolamide diminishes oxidative stress in patients with glaucoma.

The protective effects of prostaglandin analogues (bimatoprost, travoprost, and latanoprost) on oxidative stress-induced trabecular meshwork changes in primary open angle glaucoma was studied in primary cell cultures of human trabecular meshwork and furthermore whether these protective effects of prostaglandin analogues could be blocked by pretreatment with prostaglandin $\mathrm{F}$ receptor antagonists was investigated ( $\mathrm{Yu}$ et al., 2008). The cells were exposed to hydrogen peroxide $\left(\mathrm{H}_{2} \mathrm{O}_{2}\right)$ for 1 hour. The effects of prostaglandin analogues and benzalkonium chloride, which is the most widely used preservative in commercially available eye drops, on trabecular meshwork were investigated by preincubation of nonstressed or hydrogen peroxide $\left(\mathrm{H}_{2} \mathrm{O}_{2}\right)$-treated cells with 1:100 diluted commercial solutions of bimatoprost, travoprost, and latanoprost or their corresponding BAC concentrations. Pretreatment with BAC further increased the typical glaucomatous trabecular meshwork changes, which were characterized by cell loss, increased accumulation of extracellular matrix and cellular senescence in vitro. These effects were reduced by preincubation with prostaglandin analogues in hydrogen peroxide $\left(\mathrm{H}_{2} \mathrm{O}_{2}\right)$ treated and non-stressed cells. There was no reduction in the presence of prostaglandin $\mathrm{F}$ 
receptor antagonists in hydrogen peroxide $\left(\mathrm{H}_{2} \mathrm{O}_{2}\right)$-treated cells. These data suggest that oxidative stress-induced trabecular meshwork changes can be minimized by the use of prostaglandin analogues and prevention of oxidative stress exposure to the trabecular meshwork may help to reduce the progression of primary open angle glaucoma.

A refined monosodium luminal, Galavit, has antioxidant and antiinflammatory effects in human (Butorov et al., 2005) and glaucomatous mice (Jiang et al., 2006). The immunohistochemical distribution of glutathione, glutamine synthetase, and glutamate was examined in normal C57BL/6 mice (negative control), glaucomatous DBA2J mice (positive control), and glaucomatous DBA/2J mice treated with Galavit (Gionfriddo et al., 2009). Serial sections were immunogold stained for glutamate, glutamine synthetase and total glutathione, followed by image analysis for staining patterns and density. Focal decreases in glutamate immunostaining were common in the inner nuclear layer of glaucomatous DBA/2J retinas, but not in C57BL/6 or Galavit-treated glaucomatous DBA/2J retinas. Decreases in glutathione and glutamine synthetase immunostaining were found in glaucomatous DBA/2J retinal regions where neuronal glutamate immunostaining was reduced. Retinas from Galavit-treated glaucomatous DBA/2J had no significant decreases in inner nuclear layer levels of glutamate, glutathione, or glutamine synthetase. The data suggest that the antioxidant Galavit may prove to be effective in delaying or preventing retinal dysfunction and damage in at least some types of glaucoma.

\section{Conclusions}

Oxidative and nitrative processes have an important role in the pathogenesis of glaucomatous neurodegeneration (figure 5).

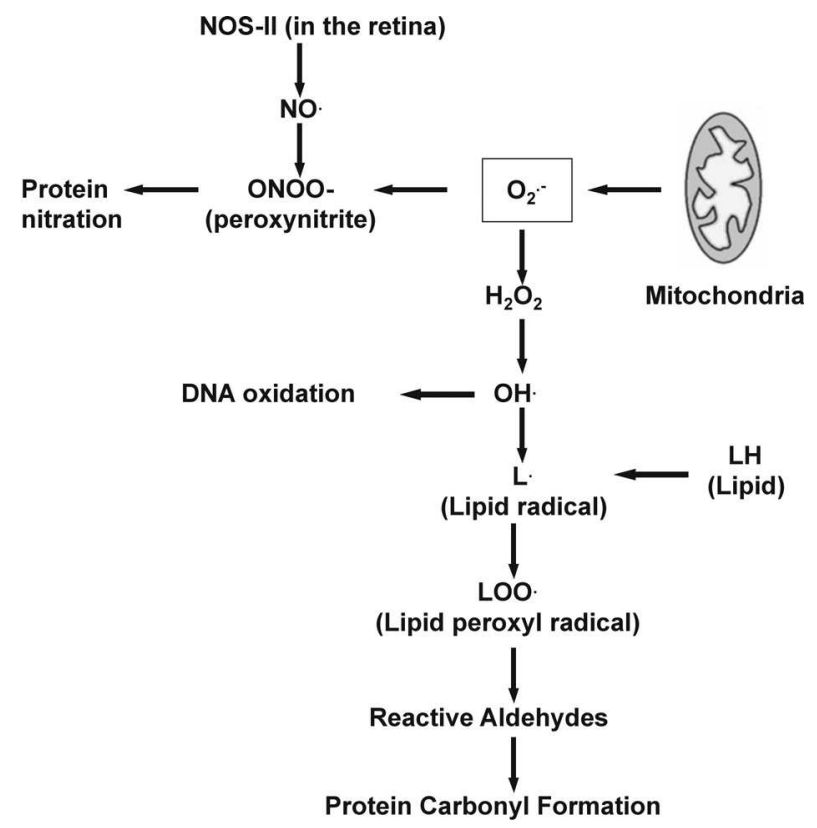

Fig. 5. Scheme of retinal oxidative damage 
Despite all documentation of experimental data there is still limited understanding to whether free radical generation is a primary or a secondary event in glaucomatous neurodegeneration. As discussed herein, oxidative damage in the cellular components of the trabecular meshwork could directly affect the regulation of the extracellular matrix structure and lead to an alteration in the flow of the aqueous humor. Perturbation of the eye's outflow will thus cause an elevation in intraocular pressure, leading to clinical onset of glaucoma. In such set of circumstances, oxidative stress can be considered as a secondary event in the pathogenesis of glaucoma. Retinal oxidative injury occurring in models of elevated intraocular pressure or in normal tension glaucoma could also directly damage the retinal ganglion cell layer, leading to glaucomatous optic neuropathy. Continued trials of therapeutic interventions to reduce in vivo oxidative stress seem relevant in patients with the disease. Probably, an effective mode of protective therapy would be to start the therapeutic interventions at an early stage of the disease and target specific sites of reactive species generation. It is desirable that future studies and clinical trails will further advance our understanding on mechanisms of neuronal degeneration in glaucoma and help in the design of more effective therapies.

\section{Acknowledgement}

This work was supported by a grant from Akdeniz University Research Foundation (No.: 2007.01.0103.018).

\section{References}

Albrecht J., Sonnewald U., Waagepetersen H. S., \& Schousboe A. (2007) Glutamine in the central nervous system:function and dysfunction. Front Biosci. 1, 12, (Jan 2007), 332-43.

Alderton W. K., Cooper C. E., \& Knowles R. G. (2001). Nitric oxide synthases: structure, function and inhibition. Biochem J. 357(Pt 3), (Aug 2001), 593-615.

Andrews R. M., Griffiths P. G., Johnson M. A. \& Turnbull D. M. (1999). Histochemical localisation of mitochondrial enzyme activity in human optic nerve and retina. $\mathrm{Br} \mathrm{J}$ Ophthalmol. 83, 2, (Feb 1999), 231-5.

Aslan M., Freeman B. A. (2007). Redox-dependent impairment of vascular function in sickle cell disease. Free Radic Biol Med. 43, 11, (Dec2007), 1469-83.

Aslan M., Ryan T. M., Townes T. M., Coward L., Kirk M. C., Barnes S., Alexander C. B., Rosenfeld S. S., \& Freeman BA. (2003) .Nitric oxide-dependent generation of reactive species in sickle cell disease. Actin tyrosine induces defective cytoskeletal polymerization. J Biol Chem. 278, 6, ( Feb 2003), 4194-204.

Aslan M., Yücel I., Akar Y., Yücel G., Ciftçioğlu M. A., \& Sanlioglu S. (2006) Nitrotyrosine formation and apoptosis in rat models of ocular injury. Free Radic Res. 40, 2, (Feb 2006), 147-53.

Aslan M., Yucel I., Ciftcioglu A., Savaş B., Akar Y., Yucel G., \& Sanlioglu S.(2007) Corneal protein nitration in experimental uveitis. Exp Biol Med (Maywood).232, 10, (Nov 2007), 1308-13.

Asregadoo, E. R. (1979). Blood levels of thiamine and ascorbic acid in chronic open-angle glaucoma. Ann Ophthalmol. 11, 7, (Jul 1979), 1095-1100.

Babior B. M., Lambeth J. D., \& Nauseef W. (2002). The neutrophil NADPH oxidase. Arch Biochem Biophys. 397, 2, (Jan 2002), 342-4. 
Babizhayev M. A, Bunin AYa. (1989). Lipid peroxidation in open-angle glaucoma. Acta Ophthalmol (Copenh). 67, 4, (Aug 1989), 371-7.

Beckman J. S., Beckman T. W., Chen J., Marshall P. A., \& Freeman B. A. (1990). Apparent hydroxyl radical production by peroxynitrite: implications for endothelial injury from nitric oxide and superoxide. Proc Natl Acad Sci U S A. 87, 4,(Feb 1990), 1620-4.

Becquet F., Courtois Y., \& Goureau O. (1997). Nitric oxide in the eye: multifaceted roles and diverse outcomes. Surv Ophthalmol. 42, 1, (Jul-Aug 1997), 71-82.

Bergamini C. M., Gambetti S., Dondi A., \& Cervellati C. Oxygen, reactive oxygen species and tissue damage. Curr Pharm Des. 10, 14, (2004),1611-26.

Bierhaus A., Hofmann M. A., Ziegler R., \& Nawroth P. P. (1998) AGEs and their interaction with AGE-receptors in vascular disease and diabetes mellitus. I. The AGE concept. Cardiovasc Res. 37 ,3, (Mar 1998), 586-600

Blair I. A. (2008). DNA adducts with lipid peroxidation products. J Biol Chem.283, 23, (Jun 2008), 15545-9.

Brownlee M., Cerami A., \& Vlassara H. (1988). Advanced glycosylation end products in tissue and the biochemical basis of diabetic complications. N Engl J Med. 318, 20, (May 1988), 1315-21.

Butorov I. V., Nikolenko, I. A., \& Butorov S. I. (2005). Efficacy of galavit in patients with duodenal ulcer. Klin Med (Mosk). 83, 8, (2005), 72-5.

Caprioli J., Ishii Y., \& Kwong J. M. Retinal ganglion cell protection with geranylgeranylacetone, a heat shock protein inducer, in a rat glaucoma model. Trans Am Ophthalmol Soc. 101, (2003), 39-50; discussion 50-1.

Caprioli J., Kitano S., \& Morgan J. E. (1996). Hyperthermia and hypoxia increase tolerance of retinal ganglion cells to anoxia and excitotoxicity. Invest Ophthalmol Vis Sci. 37, 12,(Nov 1996), 2376-81.

Cassina A. M., Hodara R., Souza J. M., Thomson L., Castro L., Ischiropoulos H., Freeman B. A., Radi R. (2000). Cytochrome c nitration by peroxynitrite. J Biol Chem. 275, 28, (Jul 2000), 21409-15.

Chakravarthy U., Stitt A. W., McNally J., Bailie J. R., Hoey E. M., \& Duprex P. (1995). Nitric oxide synthase activity and expression in retinal capillary endothelial cells and pericytes. Curr Eye Res. 14, 4, (Apr 1995), 285-94.

Chance B., Sies H., \& Boveris A. (1979). Hydroperoxide metabolism in mammalian organs Physiol Rev. 59, 3, (Jul 1979), 527-605.

Chen F., Castranova V., Shi X., \& Demers L. M.(1999). New insights into the role of nuclear factor-kappaB, a ubiquitous transcription factor in the initiation of diseases. Clin Chem. 45, 1, (Jan 1999), 7-17.

Choi J. H., Ryu Y.W., \& Seo J. H. (2005). Biotechnological production and applications of coenzyme Q10. Appl Microbiol Biotechnol.68, 1, (Jul 2005), 9-15.

Choi J., Kim K. H., Jeong J., Cho H. S., Lee C. H., \& Kook M. S. Circadian fluctuation of mean ocular perfusion pressure is a consistent risk factor for normal-tension glaucoma. Invest Ophthalmol Vis Sci. 48, 1, (Jan 2007), 104-11

Chung H.S., Haris A., Kristinsson J. K., Ciulla T. A., Kagemann C., \& Ritch R. (1999). Ginkgo biloba extract increases ocular blood flow velocity. J Ocul Pharmacol Ther. 15, 3, (Jun 1999), 233-40.

Collins A. R., Horváthová E. (2001). Oxidative DNA damage, antioxidants and DNA repair: applications of the comet assay. Biochem Soc Trans. 29, 2, (May 2001), 337-41. 
Cort A., Ozturk N., Akpinar D., Unal M., Yucel G., Ciftcioglu A., Yargicoglu P., Aslan M. (2010) Suppressive effect of astaxanthin on retinal injury induced by elevated intraocular pressure. Regul Toxicol Pharmacol. 58, 1, (Oct 2010), 121-30.

Costarides A. P., Riley M. V. \& Gren K. (1991). Roles of catalase and the glutathione redox cycle in the regulation of anterior-chamber hydrogen peroxide. Ophthalmic Res. 23, 5, (1991), 284-94.

Daff S. (2010). NO synthase: structures and mechanisms. Nitric Oxide. 23, (Aug 2010), 1-11.

Danshina P. V., Schmalhausen E. V., Avetisyan A. V., \& Muronetz V. I. (2001). Mildly oxidized glyceraldehyde-3-phosphate dehydrogenase as a possible regulator of glycolysis. IUBMB Life. 51, 5, (May 2001), 309-14.

De La Paz M. A., Epstein D. L. (1996). Effect of age on superoxide dismutase activity of human trabecular meshwork. Invest. Ophthalmol. Vis. Sci. 37, (1996), 1849-1853.

Dickinson D. A., Iles K. E., Watanabe N., Iwamoto T., Zhang H., Krzywanski D. M., \& Forman H. J. (2002). 4-hydroxynonenal induces glutamate cysteine ligase through JNK in HBE1 cells. Free Radic. Biol. Med. 33, 7, (Oct 2002), 974.

Dickinson D. A., Levonen A. L., Moellering D. R., Arnold E. K., Zhang H., Darley-Usmar V. M., \& Forman H. J. (2004). Human glutamate cysteine ligase gene regulation through the electrophile response element. Free Radic. Biol. Med. 37, 8, (Oct 2004), 1152-1159.

Dizdaroglu M. (1992). Oxidative damage to DNA in mammalian chromatin. Mutat. Res. 275, 3-6, (Sep 1992), 331-342.

Esterbauer H., Schaur R. J., \& Zollner H. (1991). Chemistry and biochemistry of 4hydroxynonenal, malonaldehyde and related aldehydes. Free Radic. Biol. Med. 11, 1, (1991), 81-128.

Fantone J. C., Ward P. A. (1982). Role of oxygen-derived free radicals and metabolites in leukocyte-dependent inflammatory reactions. Am. J. Pathol. 107,(1982), 395-418.

Fechtner R. D., Weinreb R. N. (1994). Mechanisms of optic nerve damage in primary open angle glaucoma. Surv. Ophthalmol. 39, 1, (Jul-Aug 1994), 23-42.

Feilchenfeld Z., Yucel Y. H., \& Gupta N. (2008). Oxidative injury to blood vessels and glia of the pre-laminar optic nerve head in human glaucoma. Exp. Eye Res. 87, 5, (Nov 2008), 409-414.

Filipowicz W., Bhattacharyya S. N., \& Sonenberg N. (2008). Mechanisms of posttranscriptional regulation by microRNAs: are theanswers in sight? Nat Rev Genet 9, 5, (Nov 2008), 102-14.

Freeman B. A., Crapo J. D. (1982). Biology of disease: free radicals and tissue injury. Lab. Invest. 47, 5, (Nov 1982), 412-426.

Fridovich I. (1986). Superoxide dismutases. Adv. Enzymol. Relat. Areas Mol. Biol. 58,(1986), 61-97.

Fu M. X., Wells-Knecht K. J., Blackledge J. A., Lyons T. J., Thorpe S. R. \& Baynes J. W. (1994). Glycation, glycoxidation, and cross-linking of collagen by glucose. Kinetics, mechanisms, and inhibition of late stages of the Maillard reaction. Diabetes 43, 5, (May 1994), 676-683.

Gartaganis S. P., Patsoukis N. E., Nikolopoulos D. K., \& Georgiou C. D. (2007) Evidence for oxidative stress in lens epithelial cells in pseudoexfoliation syndrome. Eye 21, 11, (Nov 2007), 1406-1411.

Gherghel D., Griffiths H. R., Hilton E. J., Cunliffe I. A., \& Hosking S. L. (2005). Systemic reduction in glutathione levels occurs in patients with primary open-angle glaucoma. Invest. Ophthalmol. Vis. Sci. 46, 3, (Mar 2005), 877-883. 
Gionfriddo J. R., Freeman K. S., Groth A., Scofield V. L., Alyahya K., \& Madl J. E. (2009). Alpha-Luminol prevents decreases in glutamate, glutathione, and glutamine synthetase in the retinas of glaucomatous DBA/2J mice. Vet Ophthalmol.;12, 5, (Sep-Oct 2009), 325-32.

Gottanka J., Johnson D. H., Martus P., \& Lütjen-Drecoll E. (1997). Severity of optic nevre damage in eyes with POAG is correlated with changes in the trabecular meshwork. J. Glaucoma 6, 2, (Apr 1997), 123-133.

Harada T., Harada C., Nakamura K., Quah H. M., Okumura A., Namekata K., Saeki T., Aihara M., Yoshida H., Mitani A., \& Tanaka K. (2007). The potential role of glutamate transporters in the pathogenesis of normal tension glaucoma. J. Clin. Invest. 117, (2007), 1763-1770.

Heneka M. T., Loschmann P. A., Gleichmann M., Weller M., Schulz J. B.,Wullner U., \& Klockgether T. (1998). Induction of nitric oxide synthase and nitric oxidemediated apoptosis in neuronal PC12 cells after stimulation with tumor necrosis factoralpha/lipopolysaccharide. J. Neurochem. 71, 1, (Jul 1998), 88-94.

Henry T. D., Archer S. L., Nelson D., Weir E. K., \& From A. H. (1990). Enhanced chemiluminescence as a measure of oxygen-derived free radical generation during ischemia and reperfusion. Circ. Res. 67, 6, (Dec 1990), 1453-1461.

Hogg N., Kalyanaraman B., Joseph J., Struck A., \& Parthasarathy S. (1993). Inhibition of lowdensity lipoprotein oxidation by nitric oxide. Potential role in atherogenesis. FEBS Lett. 334, 2, (Nov 1993), 170-174.

Hortelano S., Alvarez A. M., \& Boscá L. (1999). .Nitric oxide induces tyrosine nitration and release of cytochrome $\mathrm{c}$ preceding an increase of mitochondrial transmembrane potential in macrophages. FASEB J. 13, 15, (Dec 1999), 2311-2317.

Hu J., Van Eldik L. J. (1996). S100 beta induces apoptotic cell death in cultured astrocytes via a nitric oxide-dependent pathway. Biochim. Biophys. Acta.1313, (19969, 239-245.

Izzotti A. (2003). DNA damage and alterations of gene expression in chronic-degenerative diseases. Acta. Biochim. Pol. 50, 3, (Oct 2003), 145-154.

Jiang Y., Scofield V. L., Yan M., Qiang W., Liu N., Reid A. J., Lynn W. S., \& Wong P. K.(2006). Retrovirus-induced oxidative stress with neuroimmunodegeneration is suppressed by antioxidant treatment with a refined monosodium alpha-luminol (Galavit). J Virol. 80, 9, (May 2006), 4557-69.

Jun C. D., Oh C. D., Kwak H. J., Pae H. O., Yoo J. C., Choi B. M., Chun J. S., Park R. K., \& Chung H. T. (1999) Overexpression of protein kinase C isoforms protects RAW 264.7 macrophages fromnitric oxide-induced apoptosis: involvement of c-Jun Nterminal kinase/stress-activated protein kinase, p38 kinase, and CPP-32 protease pathways. J. Immunol. 162, (1999), 3395-3401.

Kalmar B., \& Greensmith L. (2009) Induction of heat shock proteins for protection against oxidative stress. Adv Drug Deliv Rev. 61, 4, (Apr 2009), 310-8.

Kanner J., German J. B. \& Kinsella J. E. (1987). Initiation of lipid peroxidation in biological systems. Crit. Rev. Food Sci. Nutr. 25, 4, (1987), 317-364.

Kim Y. M., Bombeck C. A. \& Billiar T. R. (1999). Nitric oxide as a bifunctional regulator of apoptosis. Circ. Res. 84, 3, (Feb 1999), 253-256.

Ko M. L., Peng P. H., Ma M. C., Ritch R., \& Chen C. F. (2005). Dynamic changes in reactive oxygen species and antioxidant levels in retinas in experimental glaucoma. Free Radic. Biol. Med. 39, 3, (Aug 2005), 365-373.

Koliakos G. G., Konstas A. G., Schlötzer-Schrehardt U., Hollo G., Katsimbris I. E., Georgiadis N. \& Ritch R. (2003). 8-Isoprostaglandin F2a and ascorbic acid concentration in the 
aqueous humour of patients with exfoliation syndrome. Br. J. Ophthalmol. 87, 3, (Mar 2003), 353-356.

Kruman I., Bruce-Keller A. J., Bredesen D., Waeg G., \& Mattson M. P. (1997). Evidence that 4-hydroxynonenal mediates oxidative stress-induced neuronal apoptosis. J. Neurosci. 17, (1997), 5089-5100.

Lancaster Jr. J. R. (1997). A tutorial on the diffusibility and reactivity of free nitric oxide. Nitric Oxide 1, 1, (Feb 1997), 18-30.

Lapolla A., Traldi P., \& Fedele D. (2005). Importance of measuring products of nonenzymatic glycation of proteins. Clin. Biochem. 38, 2, (Feb 2005), 103-115.

Lin L. (2006). RAGE on the toll road? Cell. Mol. Immunol. 3, 5, (Oct 2006), 351-358.

Lindquist S., Craig E. A.(1988). The heat-shock proteins. Annu. Rev. Genet. 22, (1988), 631677.

Linser P. J., Sorrentino M., \& Moscona A. (1984). Cellular compartmentalization of carbonic anhydrase- $\mathrm{C}$ and glutamine synthetase in developing and mature mouse neural retina. Brain Res. 315, 1, (Mar 1984), 65-71.

Liu B., Neufeld A. H. (2000). Expression of nitric oxide synthase-2 (NOS-2) in reactive astrocytes of the human glaucomatous optic nerve head. Glia 30, (2000), 178-186.

Loschen G., Azzi A., Richter C., \& Flohe L. (1974). Superoxide radicals as precursors of mitochondrial hydrogen peroxide. FEBS Lett. 42, (1974), 68-72.

Luna C., Li G., Liton P. B., Qiu J., Epstein D. L., Challa P., \& Gonzalez P. (2009a). Resveratrol prevents the expression of glaucoma markers induced by chronic oxidative stress in trabecular meshwork cells. Food Chem Toxicol. 47, 1, (Jan 2009), 198-204.

Luna C., Li G., Qiu J., Epstein D. L. \& Gonzalez, P. (2009b). Role of miR-29b on the regulation of the extracellular matrix in human trabecular meshwork cells under chronic oxidative stress. Mol Vis. 15, (Nov 2009), 2488-97.

Luo C., Yang X., Kain A. D., Powell D. W., Kuehn M. H., \& Tezel G.(2010). Glaucomatous tissue stress and the regulation of immune response through glial Toll-like receptor signaling. Invest Ophthalmol Vis Sci. 51, 11, (Nov 2010), 5697-707.

MacPherson, J. C., Comhair S. A., Erzurum S. C., Klein D. F., Lipscomb M. F., Kavuru M. S., Samoszuk M. K. \& Hazen SL. (2001). Eosinophils are a major source of nitric oxidederived oxidants in severe asthma: characterization of pathways available to eosinophils for generating reactive nitrogen species. J. Immunol. 166, 9, (May 2001), 5763-5772.

Malone P. E., Hernandez M. R. (2007). 4-Hydroxynonenal, a product of oxidative stress, leads to an antioxidant response in optic nerve head astrocytes. Exp. Eye Res. 84, (2007), 444-454.

Mannervik B., Alin P., Guthenberg C. Jensson H., Tahir M. K., Warholm M., \& Jornvall H. (1985). Identification of three classes of cytosolic glutathione transferase common to several mammalian species: correlation between structural data and enzymatic properties. Proc. Natl. Acad. Sci. U. S. A. 82, 21, (Nov 1985), 7202-7206.

Marnett L. J., Riggins J. N., \& West J. D. (2003). Endogenous generation of reactive oxidants and electrophiles and their reactions with DNA and protein. J. Clin. Invest 111, 5, (Mar 2003), 583-593.

May J. M. (1999). Is ascorbic acid an antioxidant for the plasma membrane? Faseb J. 13, 9, (Jun 1999), 995-1006.

Moreno, M. C., Campanelli J., Sande P., Sanez D. A., Keller Sarmiento M. I. \& Rosenstein R. E. (2004). Retinal oxidative stress induced by high intraocular pressure. Free Radic. Biol. Med. 37, 6, (Sep 2004), 803-812. 
Morrow J. D. (2000). The isoprostanes: their quantification as an index of oxidant stres status in vivo. Drug. Metab. Rev. 32, 3-4, (Aug-Nov 2000), 377-385.

Mozaffarieh M., Grieshaber M. C., Orgül S. \& (2008a). Flammer J. The potential value of natural antioxidative treatment in glaucoma. Surv Ophthalmol. 53, 5, (Sep-Oct 2008), 479-505.

Mozaffarieh M., Grieshaber M. C., \& Flammer J. (2008b). Oxygen and blood flow: players in the pathogenesis of glaucoma. Mol. Vis. 14, (Jan 2008), 224-233.

Neufeld A. H., Sawada A., \& Becker B. (1999). Inhibition of nitric-oxide synthase 2 by aminoguanidine provides neuroprotection of retinal ganglion cells in a rat model of chronic glaucoma. Proc. Natl. Acad. Sci. U. S. A. 96, 17, (Aug 1999), 9944-9948.

Nikjoo H., O'Neill P., Terrissol M., Goodhead D. T. (1994). Modelling of radiationinduced DNA damage: the early physical and chemical event. Int. J. Radiat. Biol. 66, 5, (Nov 1994), 453-457.

Olsen KW., Moras, D. \& Rossmann M. G. (1975). Sequence variability and structure of Dglyceraldehyde-3-phosphate dehydrogenase. J. Biol. Chem. 250, 24, (Dec 1975), 9313-9321.

Park C. S., Pardhasaradhi K., Gianotti C., Villegas E. \& Krishna G. (1994). Human retina expresses both constitutive and inducible isoforms of nitric oxide synthase mRNA. Biochem. Biophys. Res. Commun. 205, 1, (Nov 1994), 85-91.

Peng H. B., Libby P., \& Liao J. K. (1995). Induction and stabilization of I kappa B alpha by nitric oxide mediates inhibition of NF-kappa B. J. Biol. Chem. 270, (1995), 1421414219.

Perez M. T., Larsson B., Alm P., Andersson K. E., \& Ehinger B. (1995). Localisation of neuronal nitric oxide synthase-immunoreactivity in rat and rabbit retinas. Exp. Brain Res. 104, (1995), 207-217.

Poli G., Leonarduzzi G., Biasi F. \& Chiarpotto E. (2004). Oxidative stress and cell signalling. Curr. Med. Chem. 11, 9, (May 2004), 1163-1182.

Poli G., Schaur J. (2000). 4-Hydroxynonenal in the pathomechanisms of oxidative stress. IUBMB Life 50, 4-5, (Oct-Nov 2000), 315-321.

Pollack M., Yang I. Y., Kim H. Y., Blair I. A. \& Moriya M. (2006). Translesion DNA Synthesis across the heptanone-etheno-2'-deoxycytidine adduct in cells. Chem. Res. Toxicol. 19, (2006), 1074-1079.

Pratico D. (1999). F(2)-isoprostanes: sensitive and specific non-invasive indices of lipid peroxidation in vivo. Atherosclerosis. 147, 1, (Nov 1999), 1-10.

Pun P. B., Lu J. \& Moochhala S. (2009). Involvement of ROS in BBB dysfunction. Free Radic. Res. 43, 4, (Apr 2009), 348-364.

Quaranta L., Bettelli S., Uva M. G., Semeraro F., Turano R. \& Gandolfo E. (2003). Effect of Ginkgo biloba extract on preexisting visual field damage in normal tension glaucoma. Ophthalmology. 110, 2, (Feb 2003), 359-62; discussion 362-4.

Radi R., Denicola A. \& Freeman B. A. (1999). Peroxynitrite reactions with carbon dioxidebicarbonate. Methods Enzymol. 301,(1999), 353-367.

Ransohoff R. M., Perry V.H. (2009). Microglial physiology: unique stimuli, specialized responses. Annu. Rev. Immunol. 27, (2009), 119-145.

Reed J. C. (2000). Mechanisms of apoptosis. Am. J. Pathol. 157, 5, (Nov 2000),1415-1430.

Reznick A. Z., Packer L. (1994). Oxidative damage to proteins: spectrophotometric method for carbonyl assay. Methods Enzymol. 233, (1994), 357-363. 
Rhone M., Basu A. (2008). Phytochemicals and age-related eye diseases. Nutr Rev. 66, 8, (Aug 2008), 465-72.

Richer S. P., Rose R. C. (1998). Water soluble antioxidants in mammalian aqueous humor: interaction with UV B and hydrogen peroxide. Vis. Res 38, 19, (Oct 1998), 28812888.

Riley M. V. (1990). Physiologic neutralization mechanisms and the response of the corneal endothelium to hydrogen peroxide. Clao J. 16, 1, (Jan-Mar 1990), 16-21.

Ritch R. (2000). Potential role for Ginkgo biloba extract in the treatment of glaucoma. Med Hypotheses 54, 2, (Feb 2000), (221-35).

Ritch R., Schlotzer-Schrehardt U. (2001). Exfoliation syndrome. Surv. Ophthalmol. 45, 4, (JanFeb 2001), 265-315.

Ritch R., Schlotzer-Schrehardt U. \& Konstas A. G. (2003). Why is glaucoma associated with exfoliation syndrome? Prog. Retin. Eye Res. 22, 3, (May 2003), 253-275.

Roberts R. L., Green J., \& Lewis B. (2009) Lutein and zeaxanthin in eye and skin health. Clin Dermatol. 27, 2, (Mar-Apr 2009), 195-201.

Rodriguez C., Mayo J. C., Sainz R. M., Antolín I., Herrera F., Martín V. \& Reiter R. J. (2004). Regulation of antioxidant enzymes: a significant role for melatonin. J Pineal Res. 36, 1, (Jan 2004), 1-9

Rubbo H., Darley-Usmar V., \& Freeman B. A. (1996). Nitric oxide regulation of tissue free radical injury. Chem. Res. Toxicol. 9, 5, (Jul-Aug 1996), 809-820.

Sa'enz D. A., Turjanski A. G. \& Sacca G. B. (2002) Physiological concentrations of melatonin inhibit the nitridergic pathway in the Syrian hamster retina. J Pineal Res 33, 1, (Aug 2002), 31-6.

Saccà S. C., Izzotti A., Rossi P. \& Traverso C. (2007). Glaucomatous outflow pathway and oxidative stress. Exp. Eye Res. 84, (2007), 389-399.

Sacca S. C., Pascotto A., Camicione P., Capris P. \& Izzotti A. (2005). Oxidative DNA damage in the human trabecular meshwork: clinical correlation in patients with primary open-angle glaucoma. Arch. Ophthalmol. 123, 4, (Apr 2005), 458-463.

Saeki K., Kobayashi N., Inazawa Y., Zhang H., Nishitoh H., Ichijo H., Saeki K., Isemura M. \& You A. (2002). Oxidation-triggered c-Jun N-terminal kinase (JNK) and p38 mitogenactivated protein (MAP) kinase pathways for apoptosis in human leukaemic cells stimulated by epigallocatechin-3-gallate (EGCG): a distinct pathway from those of chemically induced and receptor-mediated apoptosis. Biochem. J. 368 (Pt3), (Dec 2002), 705-720.

Salmon J. F. (2008). Glaucoma. Riordan-Eva P., Whitcher J. P., Asbury T. (Eds.),. Vaughan \& Asbury's General Ophthalmology 17th ed. Chapter 11. McGraw-Hill, New York, pp. 212-222.

Sarih M., Souvannavong V. \& Adam A. (1993). Nitric oxide synthase induces macrophage death by apoptosis. Biochem. Biophys. Res. Commun. 191, 2, (Mar 1993), 503-508.

Schmalhausen E. V., Nagradova N. K., Boschi-Muller S., Branlant G. \& Muronetz V. I. (1999). Mildly oxidized GAPDH: the coupling of the dehydrogenase and acyl phosphatase activities. FEBS Lett. 452, (1999), 219-222.

Schwartz M. (2003). Macrophages and microglia in central nervous system injury: are they helpful or harmful? J. Cereb. Blood Flow Metab. 23, 4, (Apr 2003), 385-394.

Schwartz M., Kipnis J. (2002). Autoimmunity on alert: naturally occurring regulatory CD4(+)CD25(+) T cells as part of the evolutionary compromise between a 'need' and a 'risk'. Trends Immunol. 23, 11,(Nov 2002), 530-534. 
Shacter E. (2000). Protein oxidative damage. Methods Enzymol. 319, (2000), 428-436.

Shareef S., Sawada A. \& Neufeld A. H. (1999). Isoforms of nitric oxide synthase in the optic nerves of rat eyes with chronic moderately elevated intraocular pressure. Invest. Ophthalmol. Vis. Sci. 40, (1999), 2884-2891.

Shigenaga M. K., Aboujaoude E. N., Chen Q. \& Ames B. N. (1994). Assays of oxidative DNA damage biomarkers 8-oxo-2'-deoxyguanosine and 8-oxoguanine in nuclear DNA and biological fluids by high-performance liquid chromatography with electrochemical detection. Methods Enzymol. 234, (1994), 16-33.

Spiteller G. (2002). Do changes in the cell membrane structure induce the generation of lipid peroxidation products which serve as first signalling molecules in cell to cell communication? Prostaglandins Leukot. Essent. Fat. Acids 67, 2-3, (Aug-Sep 2002), 151-162..

Spiteller G. (2006). Peroxyl radicals: inductors of neurodegenerative and other inflammatory diseases. Their origin and how they transform cholesterol, phospholipids, plasmalogens, polyunsaturated fatty acids, sugars, and proteins into deleterious products. Free Radic. Biol. Med. 41, 3, (Aug 2006), 362-387.

Stadtman E. R., Berlett B.S. (1997). Reactive oxygen-mediated protein oxidation in aging and disease. Chem. Res. Toxicol. 10, (1997), 485-494.

Stadtman E. R., Oliver C. N. (1991). Metal-catalyzed oxidation of proteins. Physiological consequences. J. Biol. Chem. 266, 4, (Feb 1991), 2005-2008.

Stefani G., Slack F. J. (2008). Small non-coding RNAs in animal development. Nat Rev Mol Cell Biol. 9, 3, (Mar 2008), 219-30.

Takahashi N., Iwasaka T. \& Sugiura T. (1989). Effect of coenzyme Q10 on hemodynamic response to ocular timolol. J Cardiovasc Pharmacol 14, 3, (Sep 1989), 462-8.

Tezel G., Yang X., Luo C., Kain A. D., Powell D. W., Kuehn M. H. \& Kaplan H. J. (2010). Oxidative stress and the regulation of complement activation in human glaucoma. Invest Ophthalmol Vis Sci. 51, 10, (Oct 2010), 5071-82.

Tezel G. (2010). The immune response in glaucoma: A perspective on the roles of oxidative stres Exp Eye Res. 2010 Aug 13. [Epub ahead of print]

Tezel G., Luo C. \& Yang X. (2007). Accelerated aging in glaucoma: immunohistochemical assessment of advanced glycation end products in the human retina and optic nerve head. Invest. Ophthalmol. Vis. Sci. 48,3, (Mar 2007), 1201-1211.

Tezel G., Yang X. \& Cai J. (2005). Proteomic identification of oxidatively modified retinal proteins in a chronic pressure-induced rat model of glaucoma. Invest. Ophthalmol. Vis. Sci. 46, 9, (Sep 2005), 3177-3187.

Tomasetti M., Alleva R. \& Borghi B. (2001). In vivo supplementation with coenzyme Q10 enhances the recovery of human lymphocytes from oxidative DNA damage. FASEB J 15, 8, (Jun 2001), 1425-7.

Tripathi R. C., Chan W. F., Li J. \& Tripathi B. J. (1994). Trabecular cells express the TGF-beta 2 gene and secrete the cytokine. Exp. Eye Res. 58, 5, (May 1994), 523-528..

Vasan S., Foiles P. \& Founds H. (2003). Therapeutic potential of breakers of advanced glycation end product-protein crosslinks. Arch. Biochem. Biophys. 419, 1, (Nov 2003), 89-96.

Wallace D. C. (19999. Mitochondrial diseases in man and mouse. Science 283, (1999), 14821488.

Wu L., Fan, J. \& Belasco J. G. (2006). MicroRNAs direct rapid deadenylation of mRNA. Proc Natl Acad Sci USA. 103, 11, (Mar 2006), 4034-9. 
Xu H., Chen M. \& Forrester J. V. (2009). Para-inflammation in the aging retina. Prog. Retin. Eye Res. 28, 5, (Sep 2009), 348-368.

Xu X., Ichida J. M., Allison J. D., Boyd J. D., Bonds A. B. \& Casagrande V. A. (2001) A comparison of koniocellular, magnocellular and parvocellular receptive field properties in the lateral geniculate nucleus of the owl monkey (Aotus trivirgatus). $J$ Physiol. 531, Pt 1, (Feb 2001), 203-18.

Yagci R., Gürel A., Ersöz I., Keskin U. C., Hepşen I. F., Duman S. \& Yigitoğlu R. (2006). Oxidative stress and protein oxidation in pseudoexfoliation syndrome. Curr. Eye Res. 31,12, (Dec 2006), 1029-1032.

Yan D. B., Coloma F. M., Metheetrairut A., Trope G. E., Heathcote J. G. \& Ethier C. R. (1994). Deformation of the lamina cribrosa by elevated intraocular pressure. Br. J. Ophthalmol. 78 , 8, (Aug 1994), 643-648.

Yeo H. C., Helbock H. J., Chyu D. W. \& Ames B. N. (1994). Assay of malondialdehyde in biological fluids by gas chromatography-mass spectrometry. Anal. Biochem. 220, 2, (Aug 1994), 391-396.

Yu A. L., Fuchshofer R., Kampik A. \& Welge-Lüssen U. (2008). Effects of oxidative stress in trabecular meshwork cells are reduced by prostaglandin analogues. Invest Ophthalmol Vis Sci. 49, 11, (Nov 2008), 4872-80.

Yucel I., Akar Y., Yucel G., Ciftcioglu M. A., Keles N. \& Aslan M. (2005). Effect of hypercholesterolemia on inducible nitric oxide synthase expression in a rat model of elevated intraocular pressure. Vis. Res. 45, 9, (Apr 2005),1107-1114.

Yucel I., Yucel G., Akar Y., Demir N., Gurbuz N. \& Aslan M. (2006). Transmission electron microscopy and autofluorescence findings in the cornea of diabetic rats treated with aminoguanidine. Can. J. Ophthalmol. 41, 1, (Feb 2006), 60-66.

Yücel Y. H., Zhang Q., Weinreb R. N., Kaufman P. L. \& Gupta N. (2001) Atrophy of relay neurons in magno- and parvocellular layers in the lateral geniculate nucleus in experimental glaucoma. Invest Ophthalmol Vis Sci. 42, 13, (Dec 2001), 3216-22.

Yun A. J., Murphy C. G., Polansky J. R., Newsome D. A. \& Alvarado J. A.(1989). Proteins secreted by human trabecular cells. Glucocorticoid and other effects. Invest. Ophthalmol. Vis. Sci. 30, 9, (Sep 1989), 2012-2022.

Zanon-Moreno V., Garcia-Medina J. J., Gallego-Pinazo R., Vinuesa-Silva I., Moreno-Nadal M. A. \& Pinazo-Duran M. D. (2009). Antioxidant status modifications by topical administration of dorzolamide in primary open-angle glaucoma. Eur J Ophthalmol. 19, 4, (Jul-Aug 2009), 565-71.

Zhou L., Li Y., Yue B. Y. (1999). Oxidative stress affects cytoskeletal structure and cellmatrix interactions in cells from an ocular tissue: the trabecular meshwork. J. Cell. Physiol. 180, 2, (Aug 1999), 182-189.

Zoric L., Miric D., Milenkovic S., Jovanovic P., \& Trajkovic G. (2006). Pseudoexfoliation syndrome and its antioxidative protection deficiency as risk factors for agerelated cataract. Eur. J. Ophthalmol. 16 ,2, ( Mar-Apr 2006), 268-273. 


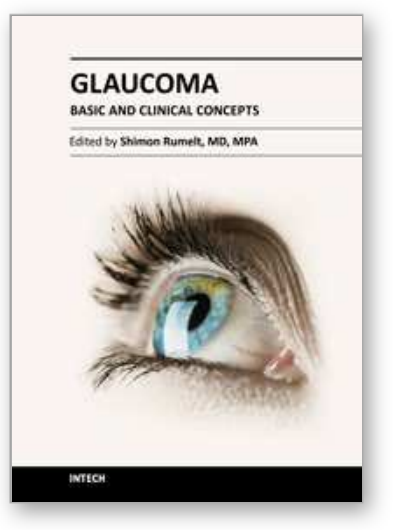

\author{
Glaucoma - Basic and Clinical Concepts \\ Edited by Dr Shimon Rumelt
}

ISBN 978-953-307-591-4

Hard cover, 590 pages

Publisher InTech

Published online 11, November, 2011

Published in print edition November, 2011

This book addresses the basic and clinical science of glaucomas, a group of diseases that affect the optic nerve and visual fields and is usually accompanied by increased intraocular pressure. The book incorporates the latest development as well as future perspectives in glaucoma, since it has expedited publication. It is aimed for specialists in glaucoma, researchers, general ophthalmologists and trainees to increase knowledge and encourage further progress in understanding and managing these complicated diseases.

\title{
How to reference
}

In order to correctly reference this scholarly work, feel free to copy and paste the following:

Serdar Dogan and Mutay Aslan (2011). The Role of Retinal Oxidative and Nitrative Injury in Glaucomatous Neurodegeneration, Glaucoma - Basic and Clinical Concepts, Dr Shimon Rumelt (Ed.), ISBN: 978-953-307591-4, InTech, Available from: http://www.intechopen.com/books/glaucoma-basic-and-clinical-concepts/therole-of-retinal-oxidative-and-nitrative-injury-in-glaucomatous-neurodegeneration

\section{INTECH}

open science | open minds

\author{
InTech Europe \\ University Campus STeP Ri \\ Slavka Krautzeka 83/A \\ 51000 Rijeka, Croatia \\ Phone: +385 (51) 770447 \\ Fax: +385 (51) 686166 \\ www.intechopen.com
}

\author{
InTech China \\ Unit 405, Office Block, Hotel Equatorial Shanghai \\ No.65, Yan An Road (West), Shanghai, 200040, China \\ 中国上海市延安西路65号上海国际贵都大饭店办公楼 405 单元 \\ Phone: +86-21-62489820 \\ Fax: $+86-21-62489821$
}


(C) 2011 The Author(s). Licensee IntechOpen. This is an open access article distributed under the terms of the Creative Commons Attribution 3.0 License, which permits unrestricted use, distribution, and reproduction in any medium, provided the original work is properly cited. 